\title{
İnsan toksokariyazı
}

\section{Human Toxocariasis}

Mehmet Burak SELEK ${ }^{1}$ Orhan BAYLAN ${ }^{1}$

\section{ÖZET}

İnsan toksokariyazı, köpek nematodu Toxocara canis ve kedi nematodu T.cati larvalarının sindirim yoluyla alınmasıyla oluşan parazitik bir enfeksiyondur. Enfekte köpek ve kedilerin dışkılarıyla dıș ortama atılan Toxocara yumurtaları içinde embriyon gelișerek enfektif hale gelirler. İnsanlar, özellikle çocuklar, embriyonlu Toxocara yumurtalarını sindirim yoluyla alarak enfekte olabilirler. İnce bağırsakta yumurtadan çıkan larvalar, ince bağırsak duvarına penetre olup kan dolașımına geçerek vücudun diğer bölgelerine göç eder. Göç eden larvalar, doku ve organlara zarar verebilmesine ve özellikle beyin tutulumunda ciddi morbidite olușturabilmesine rağmen hastalık genellikle iyi huylu, asemptomatik ve kendini sınırlayan bir seyir izlemektedir. Visseral larva migrans (VLM) (önemli organlara larval migrasyonun neden olduğu sistemik bir hastalık) ve oküler larva migrans (OLM) (göz ve optik sinirlerde sınırlı bir hastalık), toksokariyazın iki temel klinik sudur. Ayrıca son zamanlarda biri çoğunlukla çocuklarda (gizli toksokariyaz), diğeri daha çok yetișkinlerde (yaygın toksokariyaz) görülen daha hafif klinik seyirli iki sendrom daha tanımlanmıștır. Tanı, genellikle klinik belirti / bulgular, hastanın epidemiyolojik temeli ve immünolojik yöntemlerin (ELISA veya Westernblot) kullanımı ile konmaktadır. Öte yandan kesin tanının

\section{ABSTRACT}

Human toxocariasis is an parasitic infection caused by the ingestion of larvae of dog nematode Toxocara canis and less frequently of cat nematode T.cati. Toxocara eggs, shed to environment by infected dogs' and cats' droppings, become infective by embryonation. Humans, particularly children, can be infected by accidentally ingesting embryonated Toxocara eggs. Larvae hatch in the small intestine, penetrate the intestinal wall and migrate to other parts of body via the bloodstream. It is generally a benign, asymptomatic, and self-limiting disease, although migrating larvae can cause damage to tissues and organs, especially brain involvement can cause severe morbidity. The two main clinical presentations of toxocariasis are visceral larva migrans (VLM) (a systemic disease caused by larval migration through major organs) and ocular larva migrans (OLM) (a disease limited to the eyes and optic nerves). There are also two less-severe syndromes which have recently been described, one mainly in children (covert toxocariasis) and the other mainly in adults (common toxocariasis). Diagnosis is usually made by clinical signs/symptoms, epidemiological background of the patient and the use of immunological methods (ELISA or western-blot). On the other hand definitive diagnosis is much more challenging, since

GATA, Haydarpaşa Eğitim Hastanesi, Tıbbi Mikrobiyoloji Servisi, İSTANBUL

İletişim / Corresponding Author : Mehmet Burak SELEK GATA, Haydarpaşa Eğitim Hastanesi, Tibbi Mikrobiyoloji Servisi, ISTANBUL

Tel : +905053519793 E-posta /E-mail : mbselek@gata.edu.tr

DOI ID : 10.5505/TurkHijyen.2013.04875

Selek MB, Baylan O. İnsan toksokariyazı. Turk Hij Den Biyol Derg, 2013; 70(2): 113-34. 
konması, larvaların biyopsi veya otopside gösterilmesini gerektirdiğinden oldukça güçtür. Çoğu toksokariyaz olgusu, herhangi bir tedavi gerektirmeden iyileșir. VLM, birincil olarak albendazol veya mebendazol gibi antihelmintik ilaçlarla tedavi edilmektedir. OLM tedavisi ise daha zordur ve genellikle steroidler gibi gözde ilerleyici hasar oluşumunu önleyen işlemleri kapsamaktadır. Ayrıca șiddetli olguların tedavisinde lazer fotokoagülasyon ve kriyoretinopeksi kullanılabilmektedir. T.canis enfeksiyonunun eradikasyonu, parazitin yașam döngüsünün karmașıklığı sebebiyle zor olduğu için her zaman toksokariyazdan korunma tercih edilir. Toxocara yumurtaları, dış ortamda uygun koșullar altında aylarca, hatta yıllarca hayatta kalmasını sağlayan güçlü bir koruyucu tabakaya sahiptir. Bu derlemede, halen önemini koruyan ve romatolojik, dermatolojik ve respiratuvar hastalıklara neden olduğundan șüphelenilen insan toksokariyazı hakkında güncel bilgiler sunulmuștur.

Anahtar Kelimeler: Toksokariyaz, Toxocara canis, Toxocara cati, visseral larva migrans, oküler larva migrans it requires the demonstration of larvae via biopsy or autopsy. Most cases of toxocariasis clear up without any treatment. VLM is primarily treated with antihelmintic drugs, such as; albendazole or mebendazole. Treatment of OLM is more difficult and usually consists of measures to prevent progressive damage to the eye like steroids. Laser photocoagulation and cryoretinopexy may also be used to treat severe cases. Since eradicating T.canis infection is difficult due to the complexity of its life cycle, prevention of toxocariasis is always preferred. Toxocara eggs have a strong protective layer which makes the eggs able to survive in the environment for months or even years under the right conditions. In this review, current information about human toxocariasis, a continuing and important problem suspected to cause rheumatologic, dermatologic and respiratory system diseases, is presented.

Key Words: Toxocariasis, Toxocara canis, Toxocara cati, visceral larva migrans, ocular larva migrans

\section{GíRiş}

Toxocara cinsi parazitler; helmintlerin, Nematodea șubesine bağlı Secernentea sınıfının, Ascaridida takımında bulunan Ascaridoidea ailesi içinde yer alıp toksokariyaz adı verilen enfeksiyona neden olmaktadır $(1,2)$. Insanlarda toksokariyaz, başlıca iki Toxocara türü tarafından oluşturulur. Bunlar, köpeklerin nematodu T.canis ve kedilerin nematodu T.cati'dir. Yapılan çalıșmalarda insan olgularında en sık saptanan etkenin T.canis olduğu, T.cati'nin ise nadiren görüldüğü bildirilmektedir (15). Ancak Toxocara türlerinin insan olgularında sıklığı konusu tam olarak açıklığa kavușmamıștır. Macuhova ve ark.nın bir çalıșmasında (6), T.cati ile kontamine çocuk kum havuzlarından alınan yumurtaların inokule edilmesiyle farelerde enfeksiyon oluşturulmuş; farelerin çeșitli dokularından alınan larvaların polimeraz zincir reaksiyonu (PZR) yöntemiyle incelenmesinde bunların bir kısmının T.canis larvaları olduğu ortaya konmuștur. Bu durum bize moleküler yöntemlerle dahi T.canis veya T.cati ayrımının her zaman net olarak ortaya konamayabileceğini göstermektedir. Ayrıca son zamanlarda evcil kedilerde ve diğer kedigillerde birkaç Toxocara türü daha tanımlanmıștır. Bunlardan T.malayasiensis evcil kedileri, T.lyncus ise vaşakları enfekte etmektedir. Yeni tanımlanan bu türlerin insanlarda hastalık olușturup olușturmadıkları henüz kesin olarak bilinmemektedir $(1,7,8)$.

\section{TARIHÇE}

Toxocara canis, ilk defa 1782 yılında Werner tarafından tarif edilmiș ve Lumbricus canis olarak adlandırılmıştır (9). 1802 yılında Rudolphi tarafından Ascaris marginata olarak adlandırılan bu parazit; 1911 yılında Railliet tarafından Belascaris marginata olarak tanımlanmıștır (10). 
Perlingiero ve Gyorgy (11), 1947 yılında ateș, hepatomegali, hepatik granülomatöz lezyonlar, kronik hipereozinofili, hiperglobulinemi ve pulmoner değişikliklerle seyreden çocukluk yaș grubundaki hastalarını yeni bir sendrom olarak sunmuşlardır. Mercer ve ark. (12), 1950 yılında karaciğer biyopsi kesitlerinde gördükleri tipik lezyonlara dayanarak bu hastalığın patolojik ve klinik yönlerini araștırmıșlar; ancak lezyonlara neden olan bu parazitin A.lumbricoides larvaları olduğunu düşünerek Nematodea sınıfında yer alabileceğini açıklamıșlardır. Wilder (13), 1950 yılında bir çocuğun gözündeki retinal granülomda larvaların bulunduğunu gözlemlemiș ve bunların yeni bir türe ait nematod larvaları olduğunu açıklamıştır.

Behrer (14), 1951 yılında Ascaris enfestasyonu ile ilișkili olduğunu düşündüğü eozinofilik karaciğer granülomu ve hipereozinofilisi bulunan bir olgu tanımlamıștır. Beaver (15), 1952 yılında hipereozinofilisi ve uzun dönemli çoklu sistem tutulumu olan benzer üç çocuk hasta bildirmiș ve bu hastalarda VLM'nin birçok klinik bulgusunu tanımlamış; biyopsiyle alınan histopatolojik kesitlerde saptadığ etiyolojik ajanı, Toxocara olarak sınıflandırmıștır. Ayrıca bu hastalığın, iç organlar larva migransı olarak adlandırılabileceğini önermiștir.

Avustralya'da 1940 ve 1950'li ylllarda Ascarid nematodları üzerine araștırmalar yapan Sprent (9), T.canis' in köpekteki evrimini, konaklarını ve prenatal enfeksiyonunu tanımlamıștır. Smith ve Beaver (16), 1953 yılında Toxocara larvalarının insanlarda bir yıldan fazla canlı kalabileceklerini belirtmișlerdir. Milburne ve ark. (17), 1953 yılında; Gault ve Webb (18) ise 1957 yllında karaciğerde Toxocara larvalarının varlığını bildirmișler ve bu sendromun isminin larval granülamatoz olmasını önermișlerdir. Ashton (19), 1960 yılında retinal granülomla seyreden dört olgu bildirmiștir. Moore (20), 1962 yılında bir çocuğun beyninde T.canis larvalarını göstermiștir. Beaver (21), 1969 yılında insanlarda enfeksiyonun embriyonlanmıș enfektif yumurtaların sindirim yoluyla alınmasıyla geliștiğini açıklamıștır.

\section{PARAZITIN MORFOLOJISI}

\section{Yumurta}

Oval yapıdaki yumurtalar, Ascaris türlerinin yumurtaları ile yaklaşık aynı büyüklükte $(74-80 \mu \mathrm{m}$.) ve koyu kahverengindedir. Toxocara yumurtalarının yüzeylerinde tanıda belirleyici rol oynayan küçük çukurluklar bulunur $(22,23)$.

\section{Larva}

Embriyonlu yumurtadan çıkan larva, yaklașık 290-350 $\mu \mathrm{m}$. uzunluğunda, 14-20 $\mu \mathrm{m}$. çapındadır. $\mathrm{Bu}$ larvalar, histopatolojik kesitlerde yanlarında alası, çift boșaltım kanalı ve kiriș benzeri bağırsağa sahip olmasıyla tanınır. T.cati ve T.canis larvaları, aynı boyda ve çaptadır. Aynı ortamlarda bulunabilen A. lumbricoides larvası ise daha uzun (550-650 $\mu \mathrm{m})$ ve daha geniștir (24-26 $\mu \mathrm{m})$. Dıșkı ile atılan yumurtadan gelișen larvanın yaklașık 12 günde ilk gömleğini, son konak olan kedi veya köpek akciğerinde ikinci gömleğini, sindirim sistemine döndükten sonra da üçüncü ve dördüncü gömleklerini değiștirdiği bildirilmiștir (22, 24). Ayrıca bazı araștırmacılara göre larvanın yumurta içinde iki gömlek değiștirdiği ve enfektif forma bundan sonra ulaștığı bildirilmiștir. Son zamanlarda L2'den ziyade L3 tașıyan yumurtanın enfektif olduğu iddia edilmektedir $(25,26)$.

Birinci evre larvada vücut duvarı, sinir sistemi, salgısal kanallar ve sindirim sisteminin geliștiği, ikinci evrede sadece salgısal kanallarda minör değișikliklerin olduğu, üçüncü evrede sindirim sisteminin iyice belirginleșmeye ve seksüel farklılıkların gelișmeye bașladığı, dördüncü evrede ise dudak yapıları ve cinsiyetin tamamen geliștiği saptanmıștır $(22,24)$.

\section{Erişkin}

Erișkin Toxocara türlerinin ayırımında, servikal kanatlar ve erkeklerdeki perianal papillalar yardımcı olmaktadır. Erișkin T.canis erkeğinin uzunluğu, 4-10 $\mathrm{cm}$. arasında değișmektedir. Kuyruk kısmında ala ve gubernakulum bulunmamaktadır. Arka uçta parmak șeklinde bir olușuma ve kanatsız iki spiküle sahiptir. Erișkin T.canis erkeği, bunlara ek olarak yaklașık 
20 preanal papillaya sahiptir. Erișkin T.canis dișisi ise 6-18 cm. uzunluğundadır. Çift üreme organına sahiptir. Enfekte köpeğin bağırsaklarında yaklașık bir ile birkaç yüz arasında değișen erișkin T.canis paraziti bulunabilmekte ve dıșkısı ile her gün binlerce yumurta çevreye atılabilmektedir $(22,24,27,28)$.

Toxocara cati'nin servikal alası, T.canis'den daha geniștir; öne doğru incelmekte, arka uca doğru ise yuvarlaklașmaktadır. Alanın bu özelliği parazitin ön ucuna armuda benzer bir görünüm vermektedir. Yemek borusunun son kısmındaki ventrikülün boyu, eninden fazladır. Erișkin T.cati erkeği, 6 cm.; dișisi ise $12 \mathrm{~cm}$. uzunluğa kadar ulașabilmektedir. Erkeğin arka ucu çukurlașmış bir görünüme sahiptir $(22,24$, $27,28)$.

Erișkin Toxocara paraziti, Ascaridoidea ailesinde yer alan Ascaris lumbricoides'den morfolojik olarak daha küçük olması, yan taraflarında iki kanadının bulunması ve yemek borusunun arka kısmında bir genișlemeye sahip olması ile ayrılmaktadır $(1,2,4)$.

\section{YAŞAM DÖNGÜSÜ}

\section{Kedi ve köpeklerdeki yașam döngüsü}

Enfeksiyon, diș ortamda uygun șartlarda beklemiș ve içinde embriyon gelișmiș enfektif Toxocara yumurtalarının kedi ve köpekler tarafından sindirim yoluyla alınması ile başlar. Embriyonlu yumurtanın kedi ve köpeğin ince bağırsağında açılmasıyla açığa çıkan larvalar, bağırsak mukozasına penetre olur. Buradan dolașım yoluyla öncelikle karaciğere, daha sonra kalp, akciğerler ve diğer organlara göç ederler. Trakeal göçte larvalar, akciğerlerden bronşlar yoluyla trakeaya oradan farenkse ulaștıktan sonra ikinci defa yutularak bağırsak boșluğuna geçer. Larvalar, yaklașık üç haftalık bir sürede köpek ve kedilerin ince bağırsaklarındaki gelișimlerini tamamlayarak erișkin parazit haline gelir. İnce bağırsaklardaki erișkin diși ve erkeğin çiftleșmesiyle embriyonsuz yumurtalar olușur. Erișkin diși, günde yaklașık 200.000 kadar embriyonsuz yumurta bırakır. Enfekte köpek dıșkısının bir gramında 10.000-15.000 yumurta olduğu bildirilmiștir (1, 2, 4, 22-24, 29-31).

Erișkin parazitlerin hayvanlarda ortalama dört ay yașadıkları ve çoğunlukla altı aydan önce konaktan atıldıkları bildirilmektedir (5). Yumurta, kedi ve köpek dıșkısı ile dıșarı atıldığında enfektif değildir. Embriyon gelișimi, 3-4 haftalık bir sürede uygun isı $\left(15-35^{\circ} \mathrm{C}\right)$, nem (\%85) ve oksijen varlığında toprakta gerçekleșir. Yumurtalar, güneș ıșığından korunursa toprakta aylarca canlı kalabilmektedirler. Ayrıca yağmur suları ile farklı bölgelere tașınabildikleri de bildirilmiștir (1, 23, 32).

Toxocara canis'in yașam dönguisü: Beș haftalıktan daha küçük yavru köpeklerde T.canis larvaları ile enfekte gebe köpeklerde transplasental yol ile yavru köpeğe geçmesiyle prenatal toksokariyaz meydana gelmektedir. Transplasental geçiş, en erken 42. gebelik gününde olur. Larva (L2), transplasental olarak yavru köpek karaciğerine ulașır ve doğuma kadar karaciğerde barınır. Larva, doğumdan sonra akciğerlere geçerken L3 formuna döner. Sonrasında L3 larva, farinks ve mideden geçerek bağırsaklara ulașır. Burada L4 formuna dönüșür. Yavru köpekler, dördüncü haftadan itibaren dıșkılarıyla embriyonsuz yumurtaları diș ortama atmaya bașlarlar. Diğer bir yol ise transmammariyan geçiștir. Memeye gelen L2 larva, meme bezinde L3 formuna dönüșür. Yavru köpek L3 formunu süt ile alır. Beș haftadan büyük yavru köpeklerle yetișkin köpekler enfektif yumurtayı direk gastrointestinal sistem yoluyla alırlar. Trakeal göç, sistemik göçle aynı olacak șekilde L3 formunda gözlenir. Ayrıca paratenik konakların yenmesiyle, bu konakların dokularında bulunan L2 formdaki larvayı gastrointestinal yol ile alırlar $(2,33)$.

Toxocara cati'nin yaşam dönguisü: Fare gibi paratenik konaklar, T.cati'nin yaşam döngüsünde kedilerin farelere olan avlanma içgüdüsünden dolayı çok daha belirgin rol oynarlar. Prenatal geçiş görülmez. Transmammariyan geçiș, yavrulara ana bulaş yoludur. Ayrıca T. canis'ten farklı olarak trakeal göç, L2 formunda gerçekleșir. Paratenik konakların 
yenmesiyle, bu konakların dokularında bulunan L2 formundaki T.cati larvalarının gastrointestinal yol ile alımı görülmektedir (33). Bunların dışında, kedi ve köpekler paraziti enfekte hayvanların dıșkı veya kusmuklarıyla çevreye atılan geç evre larva veya olgunlașmamıș erișkinleri oral yolla alabilirler (2, 33, 34).

\section{İnsan ve diğer canlılarda yaşam döngüsü}

Enfektif (embriyonlanmış) Toxocara yumurtaları, insanlar veya diğer canlılar tarafından oral yolla alındığında hastalık bașlar. Embriyonlu yumurtalar, bu canlıların ince bağırsaklarında açılır ve serbest kalan larvalar, bağırsak mukozasına penetre olur. Daha sonra mukozadan portal dolașıma geçer ve öncelikle karaciğere, oradan vasküler yapılar aracılığıyla diğer doku ve organlara gidebilir. Ancak bu larvalar, kedi ve köpeklerde olduğu gibi tekrar bağırsağa dönüp olgunlașamamaktadır. Larvalar, sadece yerleștiği dokuda ve değișime uğramadan kalır $(1,4,22,26$, 35, 36). Parazitin yașam döngüsünün bu șekilde tamamlanamadığı konaklara, paratenik konak denir. Toksokariyaz açısından paratenik konaklar, insanın yanısıra fare, toprak solucanı, kene, tavuk, koyun, domuz ve kușlardır (22). Parazitin yașam döngüsü, paratenik konakların köpek veya kediler tarafından yenmesiyle tamamlanmıș olur $(1,22,36)$.

\section{KLINIK BULGULAR}

Toksokariyaz hastalarında çok farklı belirti ve bulguların gözlenebilmesine karșın çoğu asemptomatiktir $(22,23,37)$. Parazitin konağa verdiği zararın derecesi ve beraberinde olușturduğu klinik belirti ve bulgular, hastalığın etkilediği organa, enfeksiyonun șiddetine ve süresine göre değișkenlik gösterir. Klinik seyri etkileyen faktörler, yaș ve bağıșık durum gibi konağa ait faktörler ile dokulara göç eden larvaların sayısıdır (1, 22, 23, 37-39).

Toksokariyazın klinik

görünümleri, etkilediği organa göre $i k i$ ana sendrom içinde sınıflandırılmaktadır. Bunlar; organ hastalıklarını içine alan visseral larva migrans (VLM) ile konağın göz tutulumuyla sınırl patolojik etkilerin ve görme kaybı, șaşılık, üveit, endoftalmit, retinal granülom gibi daha organa özgül belirti ve bulguların görüldüğü oküler larva migrans (OLM) sendromlarıdır. Ayrıca son zamanlarda daha çok çocuklarda görülen gizli toksokariyaz ve genellikle yetișkinlerde izlenen yaygın toksokariyaz olarak adlandırılan özgül olmayan klinik ve laboratuvar bulgularına sahip klinik sendromlardan da bahsedilmektedir (1, 2, 4, 29-31, 40, 41).

\section{Visseral Larva Migrans (VLM)}

VLM, kesin konağı insan olmayan larvalarla gelișen, daha sık olarak çocuklarda görülen, ateș, kilo kaybı, büyüme geriliği, astım benzeri bulgular, gastrointestinal sistem șikayetleri, epilepsi benzeri , hipereozinofili ve hipergamaglobulinemi gibi sistemik ve özgül olmayan çok çeșitli klinik belirti, bulgu ve laboratuvar verileri ile seyreden bir sendromdur (1, 21-24, 28, 32, 34, 42, 43). VLM, eș anlamda kullanılmakta ise de toksokariyazı da kapsayan genel bir tanımlamadır. VLM sunu, en sık Toxocara türlerinin larvaları oluşturmakla birlikte, diğer birçok zoonotik helmint larvası da bu ya neden olabilmektedir (21, 22, 44).

Sistemik dolaşımda seyrederken larvaların çapları büyür ve larvalar damar yüzeyini delerek etraf dokulara göç edebilirler. Dokulara göç sırasında bile çapları büyümeye devam eder. Larvaların en sık yerleștikleri organ karaciğer olmasına rağmen vücuttaki tüm organları etkileyebilmektedirler (4, 27, 32, 34, 35, 45). Larvalar, beyine veya kalp kasına göç ederse ölüme neden olabilirler $(28,46)$.

\section{Oküler Larva Migrans (OLM)}

Toxocara larvalarının göze ulașarak yerleșmesi sonucu granülomlar meydana gelmekte, göz içi basınç artmakta, görme bozuklukları, ağrı ve fotofobi olușmaktadır $(2,37,47)$. Olușan lokalize veya periferik granülomlar, retinayı sürükleyerek çarpıklık, heteropi veya makulada ayrılmaya neden olabilir $(1,48,49)$. Göze damar yoluyla tek bir larvanın bile ulașması, Toxocara endoftalmitinin olușumu için yeterlidir (37). Ayrıca üveit, papillit, keratit, optik nörit ve vitröz 
apse gelișebilmektedir $(2,37,47)$.

Görme keskinliğinin bozulma derecesi, özgül bölge tutulumuna bağlıdır $(1,44,50)$. Eğer lezyonlar merkezde olușursa görme azalır, hatta kaybolur. İleri olgular, körlükle sonuçlanabilir. Bu durumda retinanın çıkarılması bile gerekebilir (44). OLM'de olușan lezyonlar, göz tümörlerinden biri olan retinoblastomadan ve diğer koroiditlerden ayrılmalıdır (37, 44, 48).

\section{Gizli Toksokariyaz}

Gizli toksokariyaz, VLM ve OLM kategorilerine girmeyen, fakat her ikisine de benzeyen, muğlak, karmașık ve özgül olmayan klinik belirti ve bulgularla kendini gösteren ve daha çok çocuklarda izlenen toksokariyaz sendromudur. Özgül olmayan klinik belirti ve bulgular arasında ateș, baș ağrısı, karın ağrısı, kas ve eklem ağrıları, anoreksi, bulantı, kusma, letarji, uyku ve davranıș bozuklukları, farenjit, nefes darlığı, öksürük, pnömoni, lenfadenopati, hepatomegali, yorgunluk, allerjik deri döküntüleri, kronik kașıntı sayılabilir. Hipereozinofili ve IgE yüksekliği, mutlak olması gereken laboratuvar bulguları değildir $(4,30$, 51-53).

\section{Yaygın Toksokariyaz}

Genellikle yetişkin bireylerde güçsüzlük, nefes almada zorluk, karın ağrısı gibi özgül olmayan klinik belirtilerle birlikte hipereozinofili ve IgE seviyesi artışı gibi laboratuvar bulgularının görüldüğü toksokariyaz sendromudur (30).

\section{EPIDEMIYOLOJi}

Toksokariyaz, hijyenik koșulların kötü olduğu, bașıboș kedi ve köpeklerin bol bulunduğu, parazit yumurtalarının embriyonlanması için uygun ısı, nem ve toprak koșullarına sahip sıcak ve ılıman bölgelerde sık görülen bir enfeksiyondur (2, 22, 24, 28, 29, 54).

Ülkemizde insanlarda toksokariyazın insidans ve seroprevalansı, yeterli çalıșma olmaması nedeniyle henüz tam olarak bilinmemektedir (47, 55-58). Yapılmış az sayıdaki ulusal çalıșma, genelikle çeșitli yakınmaları olan çoğunluğunu çocukların oluşturduğu popülasyonlarda T.canis IgG-ELISA testi kullanılarak yapılan seroepidemiyolojik araștırmalar ya da park ve bahçelerden alınan toprak numunelerinde Toxocara yumurtalarının araștırılması șeklindedir. Yapılan seroepidemiyolojik çalıșmalardan elde edilen sonuçlar, seçilen popülasyona bağlı olarak farklılık göstermektedir (27, 47, 56-58). Ülkemizde bașıboș kedi ve köpek sayısının çokluğu ve veteriner hekim kontrolünden geçmiş kedi ve köpek sayısının azlığı düșünüldüğünde toksokariyazın yaygın olması beklenmektedir $(47,55)$.

Epidemiyolojik çalışmalarda yaşanan sorunlar

Insan toksokariyazı ile ilgili epidemiyolojik çalıșmalarda önemli sorunlar yașanmaktadır. Bunun en önde gelen nedeni, çoğu epidemiyolojik çalıșmanın serolojik verilere dayanmasıdır. Bu da etkenle karşılașma ve hastalık oluşumu arasındaki ilișkinin anlașılmasında sıkıntı olușturmaktadır. Diğer sorun, kullanılan serolojik testlerin standardizasyon eksikliğidir. Bu sebeple çalıșmaların karșılaștırılması zorlașmaktadır. Üçüncü sorun ise çalıșmaların belirli bir popülasyondan elde edilen verilere dayanmasıdır. Makro ve mikroepidemiyolojik ölçekteki farklı popülasyon gruplarında yapılan çalıșmalarda saptanan seroprevalans değișikliklerinin bir bașka sebebi, insanların parazite maruz kalma seviyesindeki farklılıklar olabilir. Seroepidemiyolojik çalıșmalardaki bir diğer sorun, oküler toksokariyaza ait epidemiyolojik verilerin hemen hemen hiç dikkate alınmamasıdır. Tüm bu sorunlar, hastalığın halk sağlığı açısından öneminin anlaşılmasını zorlaștırır (27, 42, 59, 60).

\section{İnsanlara bulaş yolları}

İnsanlara bulaş, genellikle embriyonlu Toxocara yumurtaları ile kontamine olmuş toprakla temas, enfekte evcil kedi ve köpek besleme veya kontamine olmuş yiyecek ve içeceklerin tüketilmesiyle olmaktadır (1, 4, 61-64). Paratenik konakların çiğ ya da az pișmiş etlerinin yenilmesi sonucunda larvaların sindirim yoluyla alınması ile de bulaș olabileceği 
bildirilmiștir (1, 22, 36). Kontamine toprak ile temas, enfekte kedi ve köpeklerle doğrudan temasa göre kontaminasyon açısından daha riskli bir durumdur. Bunun nedeni, Toxocara yumurtalarının embriyonlu hale gelebilmeleri için öncelikle uygun ısı ve nemdeki toprakta belirli bir zaman geçirmesi gerekliliğidir $(1,4)$.

\section{Risk faktörlerine göre Toxocara seropozitifliği}

\section{a) Cinsiyet}

Toxocara seropozitifliği, genellikle erkeklerde kadınlara oranla daha sık görülmektedir $(45,58,59$, 65-68). Chiodo ve ark. (65), 2006 yılında Arjantin'de bir kasabada, gönüllülerde yaptıkları çalıșmada seropozitifliği \%23 olarak bulmușlar; bu oranın erkeklerde $\% 26$, kadınlarda ise $\% 20,3$ olarak değiștiğini belirtmișlerdir. Stensvold ve ark. (67), Danimarka'da 2009 yılında semptomatik ve asemptomatik bireylerde seropozitifliği, erkeklerde \%5,1, kadınlarda \%2,1, toplamda \%2,4 olarak bulmușlardır. Zwolinski ve ark. (69), Polonya'da 2000 yılında 151 toksokariyaz şüpheli hastada seropozitifliği \%40,1 oranında tespit etmișler; bu oranın erkeklerde \%44,2, kadınlarda ise \%36,5 olarak değiștiğini ifade etmișlerdir. Won ve ark. (68), 2008 yılında Amerika Birleșik Devletleri (ABD)'nde altı yaș ve üstünde olan 20.395 sağlıklı bireyde yaptıkları altı yılı kapsayan çalıșmada seropozitifliği \%13,9 oranında (erkeklerde \%15,6, kadınlarda \%12,4) saptamıșlardır. Roldan ve ark. (45), 2009 yılında Brezilya'da bir kasabada yaptıkları çalıșmada Toxocara seropozitifliğini rastgele seçilmiș asemptomatik bireylerde $(\% 23,4)$, solunum yolu șikayetleri olan bireylerde $\% 46,9$, karaciğer ile ilgili şikayetleri olan bireylerde $\% 31,3$, cilt ile ilgili șikayetleri olan bireylerde $\% 18,26$, sindirim şikayetleri olan bireylerde $\% 41,7$ oranında saptamıșlar; saptadıkları seropozitif bireylerin \%71,3'ünün erkek, \%28,7'sinin kadın olduğunu belirtmișlerdir. Romano ve ark. (66), 2010 yılında Malezya'da 188 rastgele seçilmiș bireyde seropozitifliği \%4,8 olarak bulmușlar; bu oranın erkeklerde \%9,5, kadınlarda \%1 oranında olduğunu belirtmişlerdir.
Toxocara seroprevalans oranını bayanlarda daha yüksek bulan az sayıda araștırma da mevcuttur (70, 71). Havasiova ve ark. (70), Slovakya'da 1993 yılında 908 sağlıklı kan donöründe seropozitifliği istatistiksel olarak anlamlı olmamakla birlikte kadınlarda erkeklere oranla daha yüksek bulmușlardır. Stefancikova ve ark. (71), yine Slovakya'da 1993 yılında yaptıkları beș yıllık çalıșmada toksokariyaz șüphesi olan bireylerde Toxocara seroprevalansını \%17,72 oranında bulmușlar; bu oranın 15 yaș altı grupta erkeklerde $\% 20,73$, kızlarda $\% 14,69 ; 15$ yaș üstü grupta ise erkeklerde $\% 12,08$, kadınlarda $\% 20,61$ olarak değiștiğini belirtmişlerdir.

Ülkemizde yapılan bir çalıșmada Yazar ve ark. (58), 2010 yılında hastanelerinin farklı servislerinden laboratuvara başvuran 112 bireyde genel seropozitifliği \%21,4 oranında saptamıșlar; bu oranın erkeklerde $\% 27,8$, kadınlarda ise $\% 13,7$ olduğunu belirtmișlerdir. Kaplan ve ark. (72), 2008 yılında șizofreni tanısı almış 98 hastada Toxocara seropozitifliğini erkeklerde \%51, kadınlarda \%40,4 oranında tespit etmişlerdir.

\section{b) Yaş grupları}

Çalıșmalarda genellikle ileri ve çocukluk yaș gruplarında saptanan Toxocara seropozitiflik oranı, diğer yaș gruplarına göre daha fazladır. Seropozitifliğin ileri yașlarda yüksek görülmesinin nedenleri arasında yaşam süresinin artmasıyla etkene maruz kalma olassılığındaki artıș ve yașla birlikte sanitasyon kurallarına uyumun azalması; çocuklarda yüksek görülmesinin nedenleri arasında ise çocukların parklarda kontamine toprakla oynamaları, ellerini sık yıkamamaları ve toprak yeme alıșkanlıkları sayılabilir $(43,69,73,74)$. Șehir içindeki ve banliyolardaki oyun parkları, insanların evcil hayvanlarını buralarda dolaștırmalarından dolayı dıș ortam koșullarına oldukça dirençli olan enfektif yumurtalar ile yüksek oranda kontaminedir $(34,66,67,75)$. Günlük el yıkama alıșkanlığı sık olan bireylerde seropozitiflik düșük bulunmuștur. Bu durum, enfektif yumurtalarla kontamine ellerden kaynaklanan enfeksiyon ediniminin, günlük el yıkama alıșkanlığı 
sık olan bireylerde düșük olmasına bağlanabilir (43, 65, 68, 76). Çocukların toprak yemesi sonucu embriyonlanmıș Toxocara yumurtaları, topraktan doğrudan gastrointestinal sisteme alınmaktadır (43, 77, 78). Roldan ve ark. (45), toprak yeme hikayesi olan çocuklarda seropozitifliği \%80, olmayanlarda $\% 20$ olarak tespit etmişlerdir.

Ehrhard ve ark. (79), tüm dünyadaki toksokariyaz olgularının yarısından fazlasının üç yaşından küçük, bește birinin erișkin ve \%60 kadarının erkek olduğunu bildirmișlerdir. Stensvold ve ark. (67), 2009 yılında, Danimarka'da 3.247 bireyde yaș gruplarında en yüksek seropozitifliği 0-9 yaș grubunda $(\% 6,7)$, en düșük seropozitifliği ise 20-29 yaș grubunda $(\% 1,6)$ saptamıșlardır. Zwolinski ve ark. (69), 2000 yılında Polonya'da toksokariyaz șüpheli 151 hastada yaș gruplarına göre seropozitifliği 15 yaș altı çocuklarda $\% 47,16-30$ yaș arası bireylerde \%21,2, 31-45 yaș arası bireylerde \%37,5, 46 yaș ve üstü bireylerde ise $\% 47,8$ olarak saptamıșlardır. Rubinsky-Elefant ve ark. (75), 2008 yılında Brezilya'da bir köyde 403 rastgele seçilmiș bireyde seropozitifliği \%26,8 oranında bulmuşlar; yaș gruplarına göre en yüksek seropozitifliğin 1-14 yaș grubunda $(\% 36,6)$, en düșük seropozitifliğin ise $15-30$ yaș grubunda $(\% 22,5)$ olduğunu tespit etmişlerdir. Romano ve ark. (66), 2010 yılında Malezya'da 188 rastgele seçilmiș bireyde yaptıkları çalıșmada, 12 yaşından küçük çocuklarda seropozitifliği \%6,3, 13 yașından büyük bireylerde ise \%1,2 olarak saptamıșlardır. Ramdan ve ark. (80), 2000 yılında Arjantin'de 156 rastgele hastada Toxocara seroprevalansını \%39 oranında bulmuşlar; yaș gruplarına göre oranın 15 yaș altında \%46,9 iken 15 yaș üstünde \%30,6 olduğunu belirtmișlerdir.

Thompson ve ark. (78), 1986 yılında Karayipler'de yaptıkları çalıșmada çocuklarda seroprevalansı \%83 olarak bulmușlardır. Fan ve ark. (76), 2004 yılında Tayvan'da yașları 7-12 arasında değișen 329 sağlıklı çocukta seropozitifliği \%76,6; Muradian ve ark. (81), 2005 yılında Brezilya'da yașları 1-15 arasında değișen 338 sağlıklı çocukta \%26,9; Tinoco-Gracia ve ark.
(82), 2008 yılında Meksika'da 288 sağlıklı çocukta \%10,6; Liao ve ark. (83), 2010 yılında Güney Afrika'da yașları 3-12 arasında değișen 92 çocukta \%44,6 ve Santarem ve ark. (84), 2011 yılında Brezilya'da 252 çocukta \%11,1 oranında saptamıșlardır.

Ülkemizde yapılan çalıșmalardan Oğuztürk ve ark. (57), 2002 yılında ilköğretim okuluna devam eden 186 sağlıklı çocukta Toxocara seroprevalansını \%32,3 oranında bildirmișlerdir. Yazar ve ark. (58), yaș gruplarında en yüksek seropozitifliği 11-20 yaș grubunda (\%30) bulurken en düșük pozitifliği 44 yaș ve üzeri grupta (\%12) tespit etmișlerdir. Kaplan ve ark. (85), 2005 yılında "American College of Rheumatology" (ACR) kriterlerine göre romatoid artrit (RA) tanısı almıș 45 hastada yaș gruplarına göre seropozitifliği, 25-34 yaș aralığında \%42,8, 35-44 yaș aralığında \%55,5, 45-54 yaș aralığında \%10, 5564 yaș aralığında \%44,4, 65 ve üzeri yaș grubunda ise \%30 oranında saptamıșlardır. Farklı bir araștırmada Kaplan ve ark. (72), 2008 yılında șizofreni tanısı almış hastalarda Toxocara seropozitifliğini 20-29 yaș grubunda \%6,8, 30-39 yaș grubunda \%39,5, 40-49 yaș grubunda \%57,1, 50-59 yaș grubunda \%46,7, 60 yaș ve üzeri grupta ise $\% 80$ oranında tespit etmișlerdir.

\section{c) Yașam bölgesi}

Toxocara seropozitifliği açısından; kırsal ve fakir bir bölgede yașamak, orta veya ileri gelir seviyesine sahip gelișmiș bir bölgede yașamaya kıyasla daha yüksek oranlardadır. Bunun nedenleri arasında; kırsal bölgede veya șehirlerin banliyolarında yașayanların șehirlerde yașayanlara göre evcil hayvanlarla olan yakın temasın ve birlikte yașamın daha fazla olması, toprak ve hayvancılıkla uğrașın daha yaygın olması, yașadıkları bölgelerde muhtemelen alt yapı koșullarının yetersiz olması, muhtemelen eğitim seviyelerinin daha düșük olması, kișisel sanitasyon kurallarını sıklıkla göz ardı etmeleri ve sahipsiz bașiboș kedi ve köpeklerin bu bölgelerde daha fazla olması sayılabilir $(1,43,47,61-64,68-70,75,77$, 84-92). 
Conde Garcia ve ark. (86), 1989 yılında İspanya'nın kırsal ve kentsel bölgelerinde yașayan çocuklarda Toxocara seroprevalansını sirasiyla $\% 8,5$ ve $\% 4,6$ oranında bulduklarını bildirmișlerdir. Havasiova ve ark. (70), 1993 yılında Slovakya'da kırsal bölgede yașayanlarda seropozitifliği \%17,09, kentsel bölgede yașayanlarda \%11,8 oranında bulmuşlardır. Zwolinski ve ark. (69), 2000 yılında Polonya'da kırsal bölgede yașayanlarda Toxocara seropozitifliğini \%56,1, küçük șehirlerdeyașayan bireylerde $\% 30,9$, kentlerdeyașayan bireylerde ise $\% 13$ oranında tespit etmișlerdir. Won ve ark. (68), Toxocara seropozitifliğini yerleșim yerine göre değerlendirdiklerinde nüfusu bir milyondan az olan șehirlerde yașayan bireylerde $\% 12,4$, bir milyondan fazla olan șehirlerde yașayan bireylerde $\% 15$; gelir düzeyine göre değerlendirdiklerinde yoksulluk sınırının altında gelire sahip olan bireylerde \%22.9, yoksulluk sınırında veya üzerinde gelire sahip olan bireylerde \%12,3 oranında bulmuşlardır. Aynı çalıșmada ABD'de doğanlarda seropozitiflik \%12,7, ABD dıșında doğanlarda \%25,5 oranında saptanmıștır. Chiodo ve ark. (65), sanitasyon koșulları iyi olan bireylerde seropozitifliği $\% 26,1$, orta seviyede olan bireylerde \%27,6 olarak bulmușlardır.

Ülkemizde yapılan çalıșmalardan Büyükbaba ve ark. (47), 1996 yılında İstanbul'da Toxocara seropozitifliğini kırsal bölgelerde yașayan çocuklarda $\% 47,2$, kentsel bölgelerde yașayan çocuklarda \%11,9 oranında saptamıșlardır. Doğan ve ark. (87), 2007 yılında Türkiye'nin kuzeybatısında (Eskișehir, Bilecik, Kütahya, Afyon illerinde) kırsal $(n=430)$ ve kentsel $(n=141)$ bölgelerde yașayan bireylerde yaptıkları çalıșmada seroprevalansı tüm çalıșma grubunda $\% 12,9$, kırsal alanda yașayanlarda $\% 16,97$, kentte yașayanlarda \%0,71 oranında saptadıklarını bildirmișlerdir. Kaplan ve ark. (85), RA'l1 45 hastanın kırsal bölgede yașayanlarında \%62,5, kentsel bölgede yașayanlarında \%29,7 oranında Toxocara seropozitifliği tespit etmişlerdir.

\section{ç) Gelir düzeyi}

Rubinsky-Elefant ve ark. (75), düșük gelir düzeyine sahip bireylerde seropozitifliği \%32,6 oranında saptamıșlar iken en yüksek gelir düzeyine sahip grupta ise \%11,3 oranında seropozitiflik tespit etmișlerdir. Gelir seviyesine göre Toxocara seropozitifliği irdelendiğinde düșük gelir düzeyine sahip hastalarda $\% 35,2$ ve orta gelir düzeyine sahip hastalarda $\% 36,3$ oranında tespit edilmiş iken yüksek gelir düzeyine sahip hastalarda seropozitiflik saptanmamıștır (85).

\section{d) Evcil hayvan besleme}

Toxocara seropozitifliği, evcil kedi ve köpek besleme hikayesi olan bireylerde, olmayanlara göre daha yüksek bulunmuștur $(43,59,68,76-78,84,85$, 87). Özellikle köpek evleri ve pet-shoplar, Toxocara yetișkinleri için barınak olușturmaktadır. Bu yerlerde yaşam döngüleri, köpek yavrularının enfekte anneden transplasental yolla genç larvaları almalarıyla devam etmektedir. Bu yüzden evde köpek yavrusu beslemek, enfeksiyonun bulașmasında önemli bir risk faktörü olarak tanımlanmaktadır $(1,3)$. Chiodo ve ark. (65), evinde köpek besleyen bireylerde seropozitifliğ \%23 oranında tespit etmișler iken beslemeyenlerde seropozitiflik bulamamıșlardır. Rubinsky-Elefant ve ark. (75), evde köpek besleyenlerde seropozitifliği $\% 28,5$, beslemeyenlerde ise $\% 20,2$ oranında bulmuşlardır. Roldan ve ark. (45), evinde kedi veya köpek besleyenlerde seropozitifliği \%93,9, beslemeyenlerde ise $\% 6,1$ oranında saptamıșlardır.

Ülkemizde yapılan çalıșmalarda, köpeklerde T.canis kolonizasyon oranlarının \%14-50 arasında değiștiği ve $T$. canis'in köpeklerde en yaygın görülen nematodlardan biri olduğu gösterilmiștir $(47,93)$. Doğan ve ark. (87), evinde köpek besleyenlerde seropozitiflik oranını $\% 12,3$, beslemeyenlerde ise $\% 4,6$ olarak bildirmișlerdir. Kaplan ve ark. (85), 45 RA hastası arasında Toxocara seropozitifliğini evcil hayvan besleyenlerde $\% 50$, beslemeyenlerde $\% 30,3$ oranında bulmușlardır.

\section{e) Toprak yeme alıșkanlığı}

Toxocara seropozitifliği, toprak yeme alıșkanlığı olan kimselerde, bu alıșkanlığı olmayanlara göre 
daha yüksek bulunmuștur $(2,28,43,68,73,78$, 84, 85, 87, 94-96). Roldan ve ark. (45), 2009 yılında Brezilya'da bir kasabada, rastgele seçilmiș bireylerde Toxocara seropozitifliğini \%53,1, toprak yeme hikayesi olanlarda \%80, olmayanlarda ise \%20 olarak tespit etmișlerdir. Schantz ve ark. (97), 1979 yılında ABD'de yaptıkları 17 oküler toksokariyaz hastası ve retinoblastom içeren diğer oküler hastalığı bulunan 15 kontrol grubundan oluşan çalıșmada pika hikayesi olan grupta seropozitifliği istatistiksel olarak anlamlı derecede yüksek bulmușlardır.

\section{f) Eğitim duizeyi}

Won ve ark. (68), Toxocara seropozitifliğini okula gitmemiș veya ilköğretim mezunlarında \%21,6, liseyi tamamlayamamıș bireylerde \%21,8, lise mezunlarında $\% 14,1$, yüksekokul mezunlarında ise \%9 oranında bulmușlar; eğitim düzeyinin veya eğitim süresinin artmasıyla seropozitifliğin azaldığını bildirmișlerdir. Rubinsky-Elefant ve ark. (75), hiç eğitim almamıșlarda seropozitifliği \%33,7, 1-4 yıl arası eğitim görenlerde \%28,2, 5-8 yıl arası eğitim görenlerde \%24,1, sekiz yıl ve üzerinde eğitim görenlerde ise \%17,6 oranında saptamıșlar aynı șekilde eğitim süresinin artmasıyla seropozitifliğin azaldığını bildirmișlerdir.

Ülkemizde yapılmıș bir araștırmada Kaplan ve ark. (85), RA'lı 45 hastanın hiç okula gitmemiș olanlarında Toxocara seropozitifliğini \%34,7, ilköğretim mezunlarında \%38,4 ve lise mezunlarında \%33,3 oranında bulmușlar, üniversite mezunlarında ise seropozitiflik saptamamıșlardır.

\section{g) Meslek grubu}

Veteriner hekim, çiftçi, pet-shop çalıșanı gibi bu enfeksiyon açısından riskli mesleklerde çalışan bireylerde toksokariyazın ciddi bir șekilde düșünülmesi gerektiği, ancak klinik ve laboratuvar tanının zor konduğu araștırmacılar tarafından bildirilmektedir $(2,22,24,28,34,42,43,73,94-96)$. Won ve ark. (68), çiftçilik ve tarım gibi toprakla temas gerektiren ișleri yapan bireylerde seropozitifliği \%25,5, diğer ișlerle uğrașanlarda \%13,5 oranında saptamıșlardır.
Farklı bir araștırmada Kaplan ve ark. (72), 2008 yılında șizofreni tanısı almıș 98 hastada Toxocara seropozitifliğini mesleği çiftçi olanlarda \%46,2 oranında, diğer meslek gruplarında ise \%25 oranında saptamıșlardır.

Sağlıklı bireylerde ve kan donörlerinde Toxocara seropozitifliği

Stensvold ve ark. (67), 2009 yılında Danimarka'da 3.247 sağlıkı bireyde \%2,4; Nicoletti ve ark. (98) 2008 yılında İtalya'da 201 sağlıklı bireyde \%6,6; Park ve ark. (99) 2002 yılında Güney Kore'de 314 sağlıklı bireyde \%5.1; Montalvo ve ark. (100) 1994 yılında Küba'da 156 sağlıklı çocukta \%5,2; Genchi ve ark. (101) 1990 yılında İtalya'da 2.112 sağlıklı bireyde \%3,98 oranlarında Toxocara seroprevalansı saptamıșlardır.

Havasiova ve ark. (70), 1993 yılında Slovakya'da sağlıklı kan donörlerinde Toxocara seropozitifliğini \%13,65 oranında bulmușlar; bu oranın șüpheli hastalarda \%27,4'e yükseldiğini tespit etmișlerdir. Sturchler ve ark. (102) ve Jacquier ve ark. (95) sağlıklı İsviçreli kan donörlerinde yaptıkları çalıșmalarda Toxocara seroprevalansını sırasıyla \%5 ve $\% 4$ oranlarında saptamıșlardır.

\section{Hastalıklarda Toxocara seropozitifliği}

\section{a) Solunum yolu hastalıkları}

Toxocara larvaları, akciğerlere yerleșiminde akut bronșiolit, astım veya pnömoni benzeri ya neden olabilmektedir (27). Astımlı hastalarda, astımı bulunmayan hastalara nazaran Toxocara antikorlarının daha fazla bulunması, toksokariyazın astıma neden olabileceğini düșündürmüștür (27, 89, 91, 103). Fernando ve ark. (89) Sri Lanka'da 100 astım hastası ve 96 astım hastalığı olmayan iki grupta yaptıkları çalıșmada Toxocara seropozitifliğini sırasıyla \%29 ve \%10,4 oranında bulmuşlardır. Toxocara seroprevalansını Sharghi ve ark. (91), 2001 yılında ABD' de yașları 2-15 arasında değișen 95 astım 
hastası çocukta \%29,3; Chan ve ark. (103) 2001 yılında Malezya'da 66 astımlı çocukta \%21,2 oranlarında bulmuşlardır.

Ülkemizde yapılan çalıșmalardan Kuștimur ve ark. (56), 2007 yılında 124 astıml hastada Toxocara seroprevalansını \%9,7; Kuk ve ark. (104) 2006 yılında 53 yetișkin astımlı hastada \%13,2 oranda bulmuşlardır.

\section{b) Nöropsikiyatrik hastalıklar}

Yapılan fare deneylerinde enfeksiyonun 7-12. günlerinde beyin sapı ve beyincikte larva saptanmıștır. Larvalar buradan omuriliğe ve çevre dokulara göç etmiștir (35). Larvaların beyne göçü, ciddi nörolojik bozukluklara neden olabilmektedir. Eozinofilik granülomlarla birlikte beyin infarktları da görülür. Merkezi sinir sistemi tutulumu, nöropsikiyatrik semptomlara veya ensefalopatiye yol açabilmektedir. Tüm toksokariyaz hastaların \%15-20'sinde merkezi sinir sistem bulguları görülebilir. Özellikle ataksi, koma, hemiparazi, Guillian-Barre sendromu gibi belirtiler izlenebilir. Tek bir larvanın bile beyindeki epileptik alanlara göçü sonrası epilepsi görülebileceğinden nedeni bilinmeyen epilepsi olgularında akla VLM de gelmelidir (1, 44).

Nicoletti ve ark. (98) 2008 yılında İtalya'da 232 epilepsi hastasında \%16,4 $(p<0.05), 201$ sağlıklı bireyde (kontrol grubu) \%6,6; Kaplan ve ark. (105) 2004 yılında 96 mental retarde hastada \%18,8 ( $p<0.05), 85$ sağlıklı çocukta \%7,7 oranında Toxocara seropozitifliği saptamışlardır. Kaplan ve ark. (72), 2008 yılında șizofreni tanısı almıș 98 hastada Toxocara seropozitifliğini $\% 45,9$, kontrol grubunda $\% 2$ oranında bulmuşlardır.

\section{c) Romatolojik hastalıklar}

Toksokariyazın eozinofilik artritin bir formuyla dolaylı olarak bir ilișkisinin bulunduğu ortaya konmuştur (106). Ayrıca indirek immünolojik mekanizmaların (parazit lezyondan farklı bir yerde gösterilmiș) sebep olduğu özellikle Reiter sendromu olmak üzere bazı inflamatuvar mono, oligo veya poliartropati olgularında T.canis suçlanmaktadır.
Parazitik romatizmal artropati kliniği, büyük olasılıkla genetik zemin, özellikle HLA-B27 histokompatibilite antijenlerinin varlığı ile ilișkilidir. Parazitin muhtemelen immünolojik mekanizmaları tetiklediği sanılmaktadır. Her zaman görülmemekle birlikte sinoviyal hipereozinofili varlığı, bu hastalığı akla getirmelidir. Sinoviyal sivı sterildir ve herhangi bir larva içermemektedir. Parazitik romatoid artritte, artiküler deformasyon veya destrüksiyon olmamaktadır. Parazitik romatizmal hastalığın tanısı, kesin ve hızlı tedavi edilebilir inflamatuvar romatizmal hastalık olması nedeniyle önemlidir. Reaktif parazitik romatolojik hastalıklarda antiparazitik tedavinin, non-steroid anti-inflamatuvar ilaçların aksine etkili olduğu gösterilmiștir (107).

Kaplan ve ark. (85), 45 RA hastasında ve 48 sağlıklı gönüllü kontrol grubunda Toxocara seropozitifliğini araștırmıșlar; hasta grubunda \%35,6, kontrol grubunda \%8.3 oranında seropozitiflik saptamıșlardır.

\section{ç) Deri hastalıklarında Toxocara seropozitifliği}

VLM olgularında kutanöz reaksiyonlar görülmesine rağmen derinin larva ve/veya larval antijenler için bir yerleșim yeri olduğu büyük ölçüde gözden kaçmaktadır. Toksokariyazda deri lezyonlarıyla ilgili sistematik, popülasyon tabanlı araștırmalar henüz yapılmamıștır (42). Toksokariyazda cilt bulguları, iki ana bașlık altında toplanabilir. Birincisi esas klinik manifestasyonları olușturan kronik kașıntı, kronik ürtiker ve ekzema türleridir. Daha nadir görülen cilt manifestasyonları ise hipodermi, vaskülit, eozinofilik follikülit, Reiter sendromu ve Wells sendromudur (108).

Bazı hipotezlere göre toksokariyazda görülen kașıntının sebebi, diğer kaşıntı sendromlarında da görülen hipereozinofilidir. Bu sendromlarda kașıntı ve cilt bulgularının ortaya çıkması, eozinofillerin etkisiyle kutanöz kemotaktik faktörlerin salınımı ile açıklanmıștır. Diğer bir hipotez ise larval ekskretuvar sekretuvar antijenlerin proteinaz aktivitesiyle histamin salınımını tetiklemesi olabileceği bildirilmiștir (108). 
Humbert ve ark. (109), Toxocara antikor pozitifliğini kronik prurigosu olan 21 hastada \%38,1, kronik kașıntı șikayeti olan 52 hastada \%15,4, kronik ürtiker tanısı almış 51 hastada \%19,5, ekzeması olan 72 hastada \%18,6 oranında bulmuşlar; Toxocara antikor pozitifliği ile kronik prurigo ve kronik ürtiker hastalıkları arasında istatistik anlamlılık olduğunu tespit etmişlerdir. Wolfrom ve ark. (110), 1996 yılında 33 kronik ürtikerli hastada yaptıkları çalıșmada Toxocara antikor pozitifliğini (\%65), kontrol grubuna (\%21) göre istatistiksel olarak anlamlı düzeyde yüksek bulmuşlardır. Gesierich ve ark. (111), 2006 yılında hipereozinofilisi ve kașıntılı cilt bulguları bulunan bir hastada antihelmintik tedaviyle eozinofilisinde azalmayla birlikte klinik remisyon görülen toksokariyaza bağlı bir eozinofilik follikülit olgusu bildirmişlerdir. Demirci ve ark. (112), 2003 yılında yaptıkları çalıșmada kronik ürtikerli hastalarda Toxocara antikor pozitifliğini, kontrol grubu sağlıklı bireylerden yüksek bulmuşlardır.

d) Oftalmolojik hastalarda Toxocara seropozitifliği

Göz tutulumu, daha sık dört yașından büyük çocuklarda ve nadir olarak da erișkinlerde gözlenir (55). OLM, genellikle VLM'nin hafif geçirilen enfeksiyonundan sonra görülmektedir. Ancak epidemiyolojik araștırmalar, oküler hastalıkların sistemik tutulum olmadan da ortaya çıkma eğiliminde olabileceğini ortaya koymuștur $(2,22,47)$. Logar ve ark. (113), 2005 yılında Slovakya'da yașları 3-80 arasında değișen oküler toksokariyaz șüpheli 239 hastanın \%28'inde, Kwon ve ark. (114) Güney Kore'de 2011 yılında oküler toksokariyaz șüpheli 92 hastanın \%35,8'inde, Zhou ve ark. (115) Çin'de 2009-2011 yılları arasında üveit tanısı alan 1236 hastanın \%2,83'ünde Toxocara seropozitifliği saptamıșlardır.

\section{Hipereozinofili bulgusuna göre Toxocara seropozitifliği}

Helmint enfeksiyonları ile hipereozinofili arasında uzun yıllardır bilinen bir ilișki mevcutttur. Toksokariyazlı hastalarda kanda veya dokularda sıklıkla hipereozinofili meydana gelmektedir. Ancak eozinofil sayısı normal bile olsa toksokariyaz tanısından uzaklașmamak gereklidir $(65,74,116)$. Girdwood ve ark. (117), 1978 yılında İskoçya'da yaptıkları çalıșmada, hepatomegali ve açıklanamayan hipereozinofilisi olan hastaların \%16'sında, oküler lezyonu olan hastaların \%15'inde, bahar nezlesi, astım veya egzeması olan olguların \%14'ünde Toxocara seropozitifliği saptamıșlardır. Ljungstrom ve ark. (90), İsveç'te 1989 yılında sağlıklı bireyler ile hipereozinofilisi, oküler, pulmoner, hepatik veya nörolojik bozuklukları olan hasta gruplarında Toxocara seroprevalansını sırasıyla \% 7 ve $\% 25$ oranında saptamıșlardır. Fenoy ve ark. (88), 1997 yılında İspanya'da hipereozinofili, splenomegali, tekrarlayan ağrı, astım gibi klinik semptomları olan seçilmiş hasta gruplarında yaptıkları çalıșmada, 30 erișkin hastada \%23, 32.218 çocuk hastada \%33, yașı bilinmeyen 45 hastada \%18 oranında Toxocara seropozitifliği saptandığını bildirmișlerdir. Choi ve ark. (118), 2003 yılında hipereozinofilisi bulunan 15 hasta üzerinde yaptıkları çalıșmada, Toxocara seropozitifliğini \%93 oranında saptamıșlardır. Sviben ve ark. (119), 2009 yılında Hırvatistan'da yașları 3-18 arasında değișen hipereozinofilisi bulunan asemptomatik 142 çocukta Toxocara seroprevalansını \%32,1 oranında tespit etmișlerdir. Maraghi ve ark. (120), 2011 yılında İran'da hipereozinofilisi olan 100 hastada yaptıkları çalıșmada Toxocara seroprevalansını \%19 olarak bulduklarını bildirmişlerdir. Chiodo ve ark. (65), hipereozinofilisi olan bireylerde seropozitifliği \%86,9, hipereozinofilisi olmayan bireylerde \%37,6 oranında tespit etmişlerdir.

Ülkemizde yapılan çalıșmalardan Karadam ve ark. (116), 2008 yılında hipereozinofilisi olan hasta grubunda yaptıkları çalıșmada Toxocara seroprevalansını hipereozinofilik grupta \%32,6, eozinofilik olmayan grupta $\% 20,3$ oranında saptamışlardır. Benzer șekilde Demirci ve ark. (74), 2002 ylında hipereozinofilisi olan grupta Toxocara 
seropozitifliğini \%29,1, eozinofilisi olmayan grupta $\% 19,4$ oranında bulmușlardır.

\section{PATOGENEZ VE IMMÜNITE}

VLM'de oluşan patoloji, larvaların konakta olușturduğu mekanik zararla ve olușan immünopatolojik reaksiyonlarla ilișkilidir. Larvaların dokularda ölümleri, așırı duyarlılık reaksiyonlarının bașlamasına neden olmaktadır. Enflamasyon, konakta eozinofilik granülomlarla kendini gösterir. Baskın olan hücre tipi, erken dönemde nötrofil ve eozinofiller iken ileri dönemde makrofajlardır. Etkilenen dokularda, çoklu eozinofilik apseler ve allerjik tip eozinofilik granülomlar meydana gelmektedir (1, 22, 23, 37-39, 121). Konakta inflamatuvar yanit, VLM'de larvaların organ boyunca tekrarlayan göçleri sonucu olușurken OLM'de ise konak daha önceden duyarlı hale gelmeden oluşabilmektedir (1).

Parazit sayısı az ise bağışık uyarı ve dolayısıyla antikor olușumu düșük olmakta; böylece larva, serbest olarak göç edebilmektedir. Şiddetli bir enfeksiyonda ise bağıșık yanıt güçlü olduğundan larva, karaciğer, akciğer veya diğer organlara hapsedilmektedir (22, 27, 121).

Toxocara larvaları, vücutta hem sıvısal hem de hücresel bağışık sistemi uyarır. Hastalık sırasında önceleri IgM seviyesi artarken sonraki dönemde lgG seviyesi artar. Bununla birlikte diğer tüm paraziter hastalıklarda olduğu gibi total lgE antikor düzeyi ve periferik eozinofil düzeyinde artış olur $(22,27,51$, 121).

Larvaya karșı olușan konak yanıtında önce nötrofil daha sonra makrofajların baskın olduğu fagositoz olayı bașlar. Dokuya göç eden larvaya karșı kompleman ve eozinofiller saldırıya geçerler. Parazite bağlanan antikorlar komplemanı klasik yolla aktive ederken, parazitin kendisi komplemanı alternatif yoldan aktive eder. Bu olaylar sırasında konağa ait epitel hücreleri çevresinde kollagen kapsül olușur. Th2 hücrelerinin ürettiği IL-4, antikorları uyarır. Olaya karıșan IL-5 ise eozinofil proliferasyonuna katkıda bulunur.
Eozinofiller, parazitler ile savașırken bazofiller de bunlara yardımcı olur. Bazofiller, eozinofiliopoetik ve eozinofil kemotaktik faktörler salgilarlar. Interferon- $\gamma$, IgG ve makrofajları uyararak bağışık yanıtın daha etkili olmasını sağlar $(22,27,121)$.

Eozinofiller, parazit ile karșılaștığında granül içeriğini çıkartarak doğrudan paraziti öldürür. Parazitin çevresinde degranüle olmuş eozinofiller ve eozinofil granül proteinleri gözlenir. Parazit yüzeyine bağlanan eozinofilik katyonik proteinler, parazite karșı güçlü toksik etkileri ile potansiyel helmint öldürücüleridir. Diğer yandan eozinofilik oksidatif metabolizma ürünleri, helmintotoksik aktivite gösterir. Eozinofilik peroksidaz ise parazitleri öldüren hipohaloz asit olușumuna sebep olmaktadır (22, 27, 121).

Konak immünitesinden kaçabilmesi için parazitin etkili savunma mekanizmaları bulunmaktadır. Larvalar, vücutta aylar ile birkaç yıla kadar değișen zamanlarda canlı kalarak girdikleri dokularda hasara neden olmaktadırlar. Ökaryotik bir parazitin herhangi bir memelide bu kadar süre canlı kalabilmesi, nadir görülen bir durumdur. Çok sınırlı parazit türü uzun dönem hayatta kalabilmektedir. Bunlar arasında yetișkin dönemdeki Schistosoma'lar (10 ile $25 \mathrm{yll}$ ), Trichinella spiralis'in birinci dönem larvaları (10 ile $30 \mathrm{yll}$ ), bazı yetișkin filaryal nematodlar (10 ile $15 \mathrm{yll}$ ) ve birçok Taenia türünün genç larvaları (5 ile 10 yıl) sayılabilir. Toxocara da dahil olmak üzere sözkonusu parazitler benzersiz kaçış mekanizmalarını konağın bağıșıklık sisteminden kurtulmak için kazanmıșlardır $(1,2,4,22,24,29-31)$.

\section{TANI}

Tekrarlayan hipereozinofili, lökositoz, hipergamaglobulinemi, total IgE düzeyi yüksekliği, artmıș isohemaglütinin titresi, eritrosit sedimentasyon hızı (ESH) artışı, karaciğer enzim düzeylerinde yükselme ve akciğer grafisinde infiltrasyon, bu hastalıkta görülebilen non-spesifik laboratuvar bulgularıdır. Nedeni bilinmeyen ateș ve 
hipereozinofilisi olan her pediatrik hastada VLM'den șüphelenmek gerekir. Hepatomegali ve multisistem hastalık geçmişi ile toprak yeme öyküsü olan hastalara VLM tanısı koyma ihtimali daha yüksektir. Benzer șekilde tek taraflı görme kaybı ve strabismusu olan her çocukta, OLM'den șüphelenmek gerekmektedir $(1,21,32-35,42,51,65,74,116,121)$.

Toxocara enfeksiyonunun kesin tanisinın biyopsi ile konulabileceği, buna karșılık enfekte dokuların histolojik olarak değerlendirilmesinde Toxocara larvalarının bulunması ve tanınmasının çok zor olması nedeniyle biyopsinin pratik olmadığı kabul edilmektedir. İnsanlarda Toxocara larvaları erișkin formuna ulașamadığından insan dıșkısında Toxocara yumurtalarının araștırılması anlamsızdır. OLM'nin kesin histopatolojik tanısı ise ancak gözün çıkarılmasından sonra konulabilmektedir. Bu nedenle, Toxocara enfeksiyonlarının tanısı için cilt testleri ve serolojik testler önerilmiș ve bu testler geliștirilmeye çalıșılmıștır (21, 27, 30, 42).

Toxocara antijenlerine karșı antikor yanıtı, dört gün ile dört hafta içerisinde ölçülebilir düzeye gelmekte ve yillarca serumda kalabilmektedir. Serolojik testlerin önemli dezavantajı, Ascaris, Strongyloides, Fasciola ve filaryal nematodlar gibi birçok paraziter enfeksiyonda çapraz reaksiyonun görülebilmesidir (96). Glickman ve ark. (122) 1978 yılında ve Özcel ve ark. (123) 1979 yılında yaptıkları çalışmalarda, VLM'nin serolojik tanısında T.canis ve A.lumbricoides erișkinlerinin antijen olarak kullanıldığı önceki serolojik testlerde çapraz reaksiyonların fazla görüldüğünü ve testlerin yeterli duyarlılıkta olmadıklarını bildirmişlerdir. Bu yüzden serolojik testlerde kullanılan antijenin niteliği çok önemlidir. Yapılan araștırmalar erișkin Toxocara antijenlerine göre larvalarının kültür ortamında biriken çıkartı ve salgı antijenlerinin daha hassas antijenik yapıya sahip maddeler olduğunu, bu ürünlerden hazırlanan ELISA deneylerinde daha özgül ve duyarlı sonuçlar alındığını, bu testlerde çapraz reaksiyonların çok daha az izlendiğini göstermiștir.
Bu antijenlerin, en yoğun olarak enfektif larvaların yemek borularından ve oral mukozalarından salındığı tespit edilmiștir. Larvaların bağırsak mukozaları ise böyle bir özelliğe sahip değildir. Söz konusu antijenler kolay elde edilir; ayrıca absorbsiyon ve erime basamağına gereksinim duymaz. Bu nedenlerle kullanılan diğer T.canis antijenlerine oranla daha avantajlıdır. Günümüzde toksokariyazın serolojik tanısında en fazla T.canis ekskretuvar sekretuvar (TES) antijenlerinin kullanıldığı enzim ișaretli immunosorbent testi (ELISA) ve Western blotting (WB) yöntemleri tercih edilmektedir. Birçok araștırıcı, TES antijenlerinin kullanıldığı ELISA ve WB yöntemlerinin, insanlarda Toxocara enfeksiyonlarının serolojik tanısında oldukça duyarlı ve özgül olduğunu bildirmiștir (21-23, 34, 37, 56, 95, 96, 122-124). Ancak asemptomatik bireylerde ve kronik hastalarda da bu testlerin pozitif sonuç vermesi, akut enfeksiyon geçiren hastaların ayrımını engellemektedir (21, 37, 123). WB ve ELISA yöntemleri karșılaștırıldığında, her iki yöntemin birbirleriyle uyumlu olduğu, WB yönteminin diğer helmint hastalıklarıyla enfekte insan serumlarında çapraz reaksiyona bağlı problemleri nispeten eleyebildiği saptanmıștır (8).

Antijen olarak erișkin ekstraktları kullanılarak yapılan hemaglütinasyon, bentonit flokülasyon, kompleman fiksasyon, in vitro larval presipitasyon, agar presipitasyon ve indirekt floresans antikor testi (IFAT) gibi serolojik testlerin, duyarlılık ve diğer ascarid parazitler ile çapraz reaksiyon vermeleri nedeniyle özgüllükleri düşük bulunmuș ve tanı için bu testlerin yeterli olmadığı saptanmıştır $(36,37,44$, $47,50,59,64,93,121,125)$.

OLM tanısında, rutin göz muayeneleri önemlidir. Larva, nadiren gözün ön çemberinin mikroskobik olarak incelenmesi sırasında gözlenebilinir. Tanı için serumda ve göz sıvısında antikor varlığı araștırılabilir. Ancak oküler enfeksiyonlarda serum antikor düzeylerinin düşük veya negatif olabileceği; eğer hastadan intraokuler sıvı alınarak test yapılırsa testin pozitif çıkabileceği bildirilmektedir $(30,42)$. 


\section{AYIRICI TANI}

Toksokariyazın; aynı klinik belirtiler gösteren ve benzer șekilde invazyon yapan diğer parazitik hastalıklardan ayırıcı tanısının yapılması gereklidir. Bunlar arasında askariyaz, fasioliyaz, strongiloidiyaz, ankilostomiyaz, filariyaz ve şistozomiyaz bulunur. Kronik eozinofilik lösemi, Hodgkin hastalığı, ailesel hipereozinofili ve ilaçlara bağlı hipereozinofili gibi yüksek eozinofili görülebilen hastalıklardan da ayırıcı tanısının yapılması önerilmektedir (126).

\section{TEDAVI}

Toksokariyazda ortaya çıkan semptomlar, larva göçlerine bağlı olduğundan uygulanacak tedavi doğrudan larvaya yönelik olmalıdır. Günümüzde T.canis larvalarının insanlarda olușturduğu enfeksiyonların tedavisine yönelik halen etkili bir ilaca gereksinim duyulmaktadır. Henüz toksokariyaz için kanıtlanmıș kesin bir tedavi yöntemi mevcut değildir. Zaten hastaların çoğu kendiliğinden iyileștiğinden bu hastalıkta destek tedavisi daha ön plandadır (2, 22, 24, 127-129).

Toksokariyazın ilaç tedavisinde, diğer benzimidazol türevleri ile benzer etkinlik göstermekle birlikte en sık albendazol kullanılmaktadır $(128,129)$. Beș gün süreyle günde iki kere yetișkinlerde $400 \mathrm{mg}$, çocuklarda $10 \mathrm{mg} / \mathrm{kg}$ dozunda yapılan albendazol tedavisinin, antihelmintik ilaç olan tiabendazole nazaran daha etkili olduğu bildirilmektedir (2, 22, $24,127,128,130)$. Tiabendazol tedavisi ile yapılan fare çalıșmalarında, farelerde larva sayısının azaldığı, larvaların dokulara göç etmelerinin önlendiği tespit edilmiș; ancak bu ilacın etkili olabilmesi için kullanım süresinin uzun olması gerektiği saptanmıștır. Toksokariyazlı hastalarda tiabendazol, günde 1-2 sefer, oral yolla $1500 \mathrm{mg} /$ gün (25-50 mg/kg/gün) dozunda, 10-14 gün boyunca kullanılabilinir (27, 127, 131). Yaygın olarak kullanılan diğer benzimidazol türevi mebendazolü $14-21$ gün süreyle $1 \mathrm{~g} / \mathrm{gün}(20 \mathrm{mg} /$ kg/gün) dozda kullanan toksokariyazıı bazı hastalarda klinik bozuklukları düzelttiği, eozinofil sayısı ve özgül anti-Toxocara IgE seviyelerini düșürdüğü bildirilmiș olmasına rağmen gastrointestinal sistemden düşük oranda emilmesi, bu ilacın ikincil tedavi seçenekleri arasında sayılmasını gerekli kılmıștır (2, 22, 24, 27, 127, 130).

Albendazolün biyoyararlanımını arttırmaya yönelik mikrokapsül formları geliștirilmeye çalıșılmıș ve farelerde olușturulan deneysel toksokariyaz modellerinde albendazole göre tașıyıcı olarak kitosan kullanılan albendazol-kitosan mikropartiküllerinin daha etkili olduğu saptanmıștır (129).

İvermektin insanlarda ceșitli helmintik hastalıkların tedavisinde başarıyla kullanılmakla birlikte toksokariyaz tedavisindeki etkinliği, kontrollü çalıșmalar ile araștırılmadığından tam olarak bilinmemektedir (129). Toksokariyazlı farelerde öldürücülüğü kanıtlamıș diğer bir ilaç dietilkarbamazindir. Günde üç doza bölünerek, $2 \mathrm{mg} /$ $\mathrm{kg}$ dozunda, 30 gün süre ile verilebilir. İnsanlarda semptomları geriletir. Eozinofil ve antikor seviyelerini düșürür. Toksokariyaza ek olarak askariyaz varsa bu ilacın kullanılmaması önerilir. Çünkü erișkin askarisin bağırsaklardan göçünün bașlamasına ve bağırsakta yırtılmaya neden olabilir $(60,126)$. Toksokariyazın șiddetli allerjik manifestasyonlarını semptomatik kortikosteroid tedavisi baskılamakla birlikte $(49,50)$ kortikosteroidlerin akciğer ve kalp tutulumu olan kötü seyirli hastaların tedavisindeki yeri tartıșmalıdır ( 2 , 22, 24,127).

OLM tedavisi daha zordur ve antihelmintik kemoterapi yanısıra genellikle steroidler gibi gözde ilerleyici hasar oluşumunu önleyen tedaviler uygulanır. Ayrıca șiddetli olguların tedavisinde lazer fotokoagülasyon ve/veya cerrahi olarak vitrektomi ve kriyoretinopeksi uygulanabilmektedir $(49,50)$.

\section{PROGNOZ}

Toksokariyazda meydana gelen enfeksiyon 
genellikle az sayıda larva ile olușur ve buna bağlı olarak da prognozun iyi olduğu düșünülür. Semptom ortaya çıkan hastalarda bile hastalığın genelikle iyi huylu olduğu ve sekel bırakmadan iyileștiği belirtilmektedir. Ancak larvanın göz, beyin veya kalp gibi yașamsal organlara göçünün ciddi komplikasyonlara ve hatta ölümlere neden olabileceği, bazı çocuklarda görme kaybı, epilepsi ve geçici hemiparezi görülebileceği bildirilmiștir (44).

Toxocara parazitine karșı insanlarda humoral ve hücresel bağışık yanıt meydana gelmektedir. Yapılan hayvan deneylerinde oral enfeksiyondan 4-7 gün sonra antikor yanıtı saptanmıștır. Antikor olușumunun enfeksiyon bașlangıcından 3-4 hafta sonra görülebildiği ve enfeksiyonun yaklașık ikinci ayında zirve yaptığı bildirilmiștir. Alınan larva sayısı, antikor yanıtının süresini ve miktarını etkilemektedir. Yeterli sayıya ulașan duyarlılașmıș T-lenfositlerinin konakta eozinofilik granülom olușturduğu, hücresel bağıșık yanıtın larvayı öldürememesi nedeniyle larvaların uzun yıllar canlı kalabileceği belirtilmiștir. $T$ ve $B$ lenfositlerin re-enfeksiyonu önleyebildiğine ilișkin kanıt bulunamamıștır (48).

\section{KORUNMA}

Toksokariyazdan basit, fakat oldukça etkili önlemlerle kolaylıkla korunulabileceği, çevrenin Toxocara yumurtaları ile kirlenmesinin ve çocukların bu yumurtaları almalarının önlenmesi gerektiği belirtilmektedir. Kedi ve köpeklerin düzenli bir șekilde Toxocara ve diğer parazitler açısından kontrol ve antiparaziter ilaçlar ile tedavi edilmeleri, bașıboș hayvanların kontrol altına alınması, toprak yeme alıșkanlığının önlenmesi önerilmektedir (24, 44). Köpek veya kedi bağırsaklarından erișkin parazitlerin atılmasında kullanılan antihelmintikler sayesinde toksokariyaz ile etkili mücadelede edilebilir (132).

Toprağın güneș etkisiyle kurumasının ve yağmur sularının yumurtaları toprağın alt katmanlarına doğru sürüklemesinin toprağın kendi kendini temizlemesi için temel faktörlerden olduğu, toprak üstünde bırakılan dıșkının kısa süre içinde toprak solucanları tarafından toprağın daha alt katmanlarına doğru tașındığı belirtilmektedir. Ancak araștırıcılara göre toprak solucanları, sıklıkla zoonotik enfeksiyonlar için rezervuar olan birçok küçük memelinin ana yiyecek kaynaklarıdır. Toprağın bileșimi ile pozitif örnekler arasında doğrudan bir ilișki saptanamamış, saksı topraklarının iyi bir enfeksiyon kaynağı olmadığı bildirilmiștir $(55,133)$.

\section{KAYNAKLAR}

1. Despommier D. Toxocariasis: clinical aspects, epidemiology, medical ecology, and molecular aspects. Clin Microbiol Rev 2003; 16(2): 265-72.

2. Unat EK, Yücel A, Altaș K, Samastı M. Unat'ın Tıp Parazitolojisi. İnsanın ökaryonlu parazitleri ve bunlarla olușan hastalıkları. 5. Baskı. İstanbul Üniversitesi Cerrahpașa Tıp Fakültesi Vakfı Yayınları, 1995; 15: 682-860.
3. MarmorM, Glickman L, ShoferF, Faich LA, Rosenberg C, Cornblatt B, et al. Toxocara canis infection of children: epidemiologic and neuropsychologic findings. Am J Public Health 1987; 77(5): 554-9.

4. Overgaauw PA. Aspects of Toxocara epidemiology: human toxocarosis. Crit Rev Microbiol 1997; 23(3): 215-31. 
5. Sprent JFA, Barrett MG. Large roundworms of dogs and cats: differentiation of Toxocara canis and Toxascaris leonina. Aust Vet J, 1964: 40(4): 166-71.

6. Macuhova K, Akao N, Fujinami Y, Kumagai T, Ohta N. Contamination, distribution and pathogenicity of Toxocara canis and T.cati eggs from sandpits in Tokyo, Japan. J Helminthol, 2012;1-6.

7. Gibbons LM, Jacobs DE, Sani RA. Toxocara malaysiensis n. sp. (Nematoda: Ascaridoidea) from the domestic cat (Felis catus Linnaeus, 1758). J Parasitol, 2001; 87(3): 660-5.

8. Magnaval JF, Fabre R, Maurieres P, Charlet JP, de Larrard B. Application of the western blotting procedure for the immunodiagnosis of human toxocariasis. Parasitol Res, 1991; 77(8): 697-702.

9. Sprent J. Observations on the development of Toxocara canis (Werner, 1782) in the dog. Parasitology, 1958; 48(1-2): 184-209.

10. Walton AC. A revision of the nematodes of the Leidy collections. Proceedings of the Academy of Natural Sciences of Philadelphia, 1927; 79: 49-163.

11. Perlingiero J, Gyorgy P. Chronic eosinophilia; report of a case with necrosis of the liver, pulmonary infiltrations, anemia and ascaris infestation. Am J Dis Child, 1947; 73(1): 34-43.

12. Mercer R, Lund H, Bloomfield R, Caldwell F. Larval ascariasis as a cause of chronic eosinophilia with visceral manifestations. Am J Dis Child, 1950; 80(1): 46-58.

13. Wilder H. Nematode endophthalmitis. Trans Am Acad Ophthalmol Otolaryngol, 1950; 55: 99-109.

14. Behrer M. Hypereosinophilia with eosinophilic granuloma of the liver associated with ascaris infestation. J Pediatr, 1951; 38(5): 635-40.

15. Beaver P, Snyder C, Carrera G, Dent J, Lafferty J. Chronic eosinophilia due to visceral larva migrans; report of three cases. Pediatrics, 1952; 9(1): 7-19.

16. Smith $\mathrm{MH}$, Beaver PC. Persistence and distribution of Toxocara larvae in the tissues of children and mice. Pediatrics, 1953; 12(5): 491-7.

17. Milburn C, Ernst K. Eosinophilia-hepatomegaly syndrome of infants and young children; report of a case due to invasion of liver by nematode larvae. Pediatrics, 1953; 11(4): 358-67.
18. Gault E, Webb J. Tropical eosinophilia; hepatic lesions related to presence of nematode larvae. Lancet, 1957; 273(6993): 471-2.

19. Ashton N. Larval granulomatosis of the retina due to Toxocara. Br J Ophthalmol, 1960; 44:129-48.

20. Moore M. Human Toxocara canis encephalitis with lead encephalopathy. J Neuropathol Exp Neurol, 1962; 21: 201-18.

21. Beaver PC. The nature of visceral larva migrans. J Parasitol 1969;55(1):3-12.

22. Glickman LT, Schantz PM. Epidemiology and pathogenesis of zoonotic toxocariasis. Epidemiol Rev, 1981;3(1):230-50.

23. Korkmaz M. Visseral larva migrans: ikinci evre Toxocara canis larvalarının in vitro kültürü. Eksretuvar/sekretuvar antijeninin elde edilmesi ve ELISA yöntemi ile tanısı. Uzmanlık Tezi. Ege Üniv Tıp Fak, 1984.

24. Markell EK, John DT, Krotoski WA. The intestinal nematodes. The blood and tissue nematodes. Markell and Voge's Medical Parasitology. 8th ed. Philadelphia: W.B.Saunders Company, 1999; 345-6.

25. Taylor MA, Coop RL, Wall RL. Veterinary Parasitology. 3rd ed. Oxford: Wiley-Blackwell Publishing, 2007.

26. Brunaska M, Dubinsky P, Reiterova K. Toxocara canis: ultrastructural aspects of larval moulting in the maturing eggs. Int J Parasitol, 1995; 25(6): 683-90.

27. Arıkan MS. Toxocariasis hastalarında eozinofilik katyonik protein düzeylerinin araștırılması. Uzmanlık Tezi. Süleyman Demirel Üniversitesi Tıp Fakültesi Tıbbi Mikrobiyoloji ABD, 2007.

28. Saygı G. Temel Tıbbi Parazitoloji. 1. Baskı. Sivas: Esnaf Ofset Matbaacılık, 1998; 128-9.

29. Korkmaz M. Toxocariosis. In: Özcel MA, eds. Özcel'in Tıbbi Parazit Hastalıkları. Türkiye Parazitoloji Derneği Yayını No:22. İzmir, 2007; 649-60.

30. Magnaval JF, Glickman LT, Dorchies P, Morassin B. Highlights of human toxocariasis. Korean J Parasitol, 2001; 39(1): 1-11.

31. Taylor MRH, Holland CV. Toxocariasis. Gillespie $\mathrm{S}$, Pearson RD, eds. In: Principles and Practice of Clinical Parasitology. England. John Wiley and Sons Ltd, 2001. 
32. Falcone $\mathrm{FH}$, Tetteh KK, Hunt P, Blaxter ML, Loukas A, Maizels RM. The new subfamily of cathepsin-Zlike protease genes includes Tc-Cpz-1, a cysteine protease gene expressed in Toxocara canis adults and infective stage larvae. Exp Parasitol, 2000; 94(3): 201-7.

33. Johnstone C. Toxocara canis and Toxocara cati. In: Parasites and Parasitic Diseases of Domestic Animals. University of Pennsylvania, (Online book). 1998. (http://cal.vet.upenn.edu/ projects/merial/ascarids/asc_05a.html) (http:// cal.vet.upenn.edu/projects/merial/ascarids/ asc_06a.html)

34. Güngör Ç, Çiftçi E, Aral Akarsu G. Nedeni bilinmeyen karın ağrısı șikayeti olan çocuklarda Toxocara antikoru prevalansı. Türkiye Parazitol Derg, 1999;23(1): 24-7.

35. Burren $\mathrm{CH}$. The distribution of Toxocara larvae in the central nervous system of the mouse. Trans $\mathrm{R}$ Soc Trop Med Hyg, 1971; 65(4): 450-3.

36. Nagakura K, Tachibana H, Kaneda Y, Kato Y. Toxocariasis possibly caused by ingesting raw chicken. J Infect Dis, 1989; 160(4): 735-6.

37. Schantz PM. Toxocara larva migrans now. Am J Trop Med Hyg, 1989; 41(3 Suppl):21-34.

38. Kuziemski K, Jassem E, Mierzejewska E, Goljan J, Slominski JM. Lung manifestation of visceral larva migration syndrome due to Toxocara canis infection. Pneumonol Alergol Pol, 1999; 67(11-12): 554-7.

39. Sabrosa NA, de Souza EC. Nematode infections of the eye: toxocariasis and diffuse unilateral subacute euroretinitis. Curr Opin Ophthalmol, 2001;12(6):450-4.

40. Aydenizöz-Ozkayhan M, Yağci BB, Erat S. The investigation of Toxocara canis eggs in coats of different dog breeds as a potential transmission route in human toxocariasis. Vet Parasitol, 2008; 152(1-2): 94-100.

41. Pawlowski Z. Toxocariasis in humans: clinical expression and treatment dilemma. J Helminthol, 2001; 75(4): 299-305.

42. Smith H, Holland C, Taylor M, Magnaval JF, Schantz P, Maizels R. How common is human toxocariasis? Towards standardizing our knowledge. Trends Parasitol, 2009; 25(4): 182-8.

43. Selek MB. Asemptomatik ve semptomatik bireylerde toksokariyaz. Uzmanlık Tezi. GATA Haydarpaşa Eğitim Hastanesi Tıbbi Mikrobiyoloji Servisi, 2012.
44. Nash TE. Visceral larva migrans and other unusual helminth infections. In: Mandell GL, Bennett JE, Dolin R, eds. Principles and Practice of Infectious Diseases. New York, Churchill Livingstone Inc, 1995: 2553-7.

45. Roldan WH, Espinoza YA, Huapaya PE, Huiza AF, Sevilla CR, Jimenez S. Frequency of human toxocariasis in a rural population from Cajamarca, Peru determined by DOT-ELISA test. Rev Inst Med Trop Sao Paulo, 2009; 51(2): 67-71.

46. Enko K, Tada T, Ohgo KO, Nagase S, Nakamura K, Ohta K, et al. Fulminant eosinophilic myocarditis associated with visceral larva migrans caused By Toxocara canis infection. Circ J, 2009; 73(7): 1344-8.

47. Büyükbaba Ö, Özkan E, Büget E. Toxocariasis canis ve çocuklardaki seroprevalansının ELISA ile araștırılması. İnfeksiyon Derg, 1996; 10(1): 7-11.

48. Craft JC. Visceral larva migrans. In: Hoeprich PD, Jordan MC, eds. Infectious Diseases. Philadelphia, JB Lippincott Company, 1989; 825-9.

49. Small KW, McCuen BW, de Juan E Jr, Machemer R. Surgical management of retinal traction caused by toxocariasis. Am J Ophthalmol, 1989; 108(1): 10-4.

50. Dinning WJ, Gillespie SH, Cooling RJ, Maizels RM. Toxocariasis: a practical approach to management of ocular disease. Eye(Lond), 1988; 2(5): 580-2.

51. Glickman LT, Magnaval JF, Domanski LM, Shofer FS, Lauria SS, Gottstein B, et al. Visseral larva migrans in French adults: a new disease syndrome?. Am J Epidemiol, 1987; 125(6): 1019-34.

52. Taylor MR, Keane CT, O'Connor P, Girdwood RW, Smith H. Clinical features of covert toxocariasis. Scand J Infect Dis, 1987; 19(6): 693-6.

53. Bass JL, Mehta KA, Glickman LT, Eppes BM. Clinically inapparent Toxocara infection in children. N Engl J Med, 1983; 308(12): 723-4.

54. Mizgajska $\mathrm{H}$. The role of some environmental factors in the contamination of soil with Toxocara spp. and other geohelminth eggs. Parasitol Int, 1997; 46(1): 67-72.

55. Kaplan M, Gödekmerdan A, Kalkan A, Erensoy A, Özden M. Elazığ yöresinde Toxocara canis seroprevalansı (ön çalıșma). Fırat Üniv Sağlık Bilim Derg, 1999; 13(1): 51-4. 
56. Kustimur S, Dogruman Al F, Oguzulgen K, Bakir H, Maral I, Turktas $\mathrm{H}$, et al. Toxocara seroprevalence in adults with bronchial asthma. Trans R Soc Trop Med Hyg, 2007; 101(3): 270-4.

57. Oğuztürk H, Saygı G. Toxocara canis larvaları ile olușan infeksiyonun ilköğretim okulu öğrencilerinde araștırılması. Turkiye Parazitol Derg, 2002; 26(4): 409-14.

58. Yazar S, Yaman O, Cetinkaya U, Hamamci B, Sahin I. Investigation of anti-Toxocara canis IgG antibodies in patients presenting at the Erciyes University Medical Faculty, Department of Parasitology. Turkiye Parazitol Derg, 2010; 34(1): 24-6.

59. Caucanas JP, Magnaval JF, Pascal JP. Prevalence of Toxocaral disease. Lancet, 1988; 1(8593): 1049.

60. Good B, Holland CV, Taylor MR, Larragy J, Moriarty P, O'Regan M. Ocular toxocariasis in schoolchildren. Clin Infect Dis, 2004; 39(2): 173-8.

61. Castillo D, Paredes C, Zanartu C, Castillo G, Mercado R, Munoz V, et al. Environmental contamination with Toxocara sp. eggs in public squares and parks from Santiago, Chile, 1999. Bol Chil Parasitol, 2000; 55(3-4): 86-91.

62. Giacometti A, Cirioni O, Fortuna M, Osimani P, Antonicelli L, Del Prete MS, et al. Environmental and serological evidence for the presence of toxocariasis in the urban area of Ancona, Italy. Eur J Epidemiol, 2000; 16(11): 1023-6.

63. Mizgajska $\mathrm{H}$. Eggs of Toxocara spp. in the environment and their public health implications. J Helminthol, 2001; 75(2): 147-51.

64. Oge S, Oge H. Prevalence of Toxocara spp. eggs in the soil of public parks in Ankara, Turkey. Dtsch Tierarztl Wochenschr, 2000; 107(2): 72-5.

65. Chiodo P, Basualdo J, Ciarmela L, Pezzani B, Apezteguia M, Minvielle $M$. Related factors to human toxocariasis in a rural community of Argentina. Mem Inst Oswaldo Cruz 2006;101(4):397-400.

66. Romano N, Nor Azah MO, Rahmah N, Yal L, Rohela M. Seroprevalence of toxocariasis among orang asli (indigenous people) in Malaysia using two immunoassays. Trop Biomed, 2010; 27(3): 585-94.

67. Stensvold CR, Skov J, Moller LN, Jensen PM, Kapel CM, Petersen E, et al. Seroprevalence of human toxocariasis in Denmark. Clin Vaccine Immunol, 2009; 16(9): 1372-3.
68. Won KY, Kruszon-Moran D, Schantz PM, Jones JL. National seroprevalence and risk factors for zoonotic Toxocara spp. infection. Am J Trop Med Hyg, 2008; 79(4): 552-7.

69. Zwolinski J. The risk factors of Toxocara canis infestation in population of patients from the Lublin region. Wiad Parazytol, 2000; 46(4): 63-73.

70. Havasiova K, Dubinsky P, Stefancikova A. A seroepidemiological study of human Toxocara infection in the Slovak Republic. J Helminthol, 1993; 67(4): 291-6.

71. Stefancikova A, Havasiova K, Dubinsky P. Serodiagnosis of larval toxocariasis in Slovakia. Bratisl Lek Listy, 1993; 94(2): 99-102.

72. Kaplan M, Kalkan A, Kuk S, Demirdag K, Ozden M, Kilic SS. Toxocara seroprevalence in schizophrenic patients in Turkey. Yonsei Med J, 2008; 49(2): 224-9.

73. Alonso JM, Bojanich MV, Chamorro M, Gorodner JO. Toxocara seroprevalence in children from a subtropical city in Argentina. Rev Inst Med Trop Sao Paulo, 2000; 42(4): 235-7.

74. Demirci M, Korkmaz M, Sakru N, Kaya S, Kuman A. Diagnostic importance of serological methods and eosinophilia in tissue parasites. J Health Popul Nutr, 2002; 20(4): 352-5.

75. Rubinsky-Elefant G, da Silva-Nunes M, Malafronte RS, Muniz PT, Ferreira MU. Human toxocariasis in rural brazilian amazonia: seroprevalence, risk factors, and spatial distribution Am J Trop Med Hyg, 2008; 79(1): 93-8.

76. Fan CK, Hung CC, Du WY, Liao CW, Su KE. Seroepidemiology of Toxocara canis infection among mountain aboriginal schoolchildren living in contaminated districts in eastern Taiwan. Trop Med Int Health, 2004; 9(12): 1312-8.

77. Herrmann N, Glickman LT, Schantz PM, Weston MG, Domanski LM. Seroprevalence of zoonotic toxocariasis in the United States: 1971-1973. Am J Epidemiol, 1985; 122(5): 890-6.

78. Thompson DE, Bundy DA, Cooper ES, Schantz PM. Epidemiological characteristics of Toxocara canis zoonotic infection of children in a Caribbean community. Bull World Health Organ, 1986; 64(2): 283-90.

79. Ehrhard T, Kernbaum S. Toxocara canis et toxocarose humaine. Bull Inst Pasteur, 1979; 77: 225-87. 
80. Ramdan NE, Archelli SM, Fonrouge RD, del $V$ Guardis M, Linzitto OR. Human toxocarosis. Its seroprevalence in the city of La Plata. Mem Inst Oswaldo Cruz, 2000; 95(3): 281-5.

81. Muradian V, Gennari SM, Glickman LT, Pinheiro SR. Epidemiological aspects of visceral larva migrans in chidren living at Sao Remo Community, Sao Paulo (SP). Brazil Vet Parasitol, 2005; 134(1-2): 93-7.

82. Tinoco-Gracia L, Barreras-Serrano A, LopezValencia G, Tamayo-Sosa AR, Quiroz-Romero H, Melgarejo T. Seroprevalence of larva migrans of Toxocara canis and evaluation of associated risk factors among children in a Mexico-United States Border Region. Intern J Appl Res Vet Med, 2008; 6(2): 130-6.

83. Liao CW, Sukati H, D'Lamini P, Chou CM, Liu YH, Huang YC, et al. Seroprevalence of Toxocara canis infection among children in Swaziland, Southern Africa. Ann Trop Med Parasitol, 2010; 104(1): 73-80.

84. Santarem VA, Leli FN, Rubinsky-Elefant G, Giuffrida R. Protective and risk factors for toxocariasis in children from two different social classes of Brazil. Rev Inst Med Trop Sao Paulo, 2011; 53(2): 66-72.

85. Kaplan M, Kamanlı A, Kalkan A, Kuk S, Gülkesen A, Ardıçoğlu Ö, et al. Toxocariasis seroprevalence in patients with rheumatoid arthritis. Turkiye Parazitol Derg, 2005; 29(4): 251-4.

86. Conde Garcia L, Muro Alvarez A, Simon Martin F. Epidemiological studies on toxocariasis and visceral larva migrans in a zone of western Spain. Ann Trop Med Parasitol, 1989; 83(6): 615-20.

87. Doğan N, Dinleyici EC, Bor O, Töz SO, Ozbel Y. Seroepidemiological survey for Toxocara canis infection in the northwestern part of Turkey. Türkiye Parazitol Derg, 2007; 31(4): 288-91.

88. Fenoy S, Cuellar C, Guillen JL. Serological evidence of toxocariasis in patients from Spain with a clinical suspicion of visceral larva migrans. J Helminthol, 1997; 71(1): 9-12.

89. Fernando D, Wickramasinghe P, Kapilananda G, Dewasurendra RL, Amarasooriya M, Dayaratne A. Toxocara seropositivity in Sri Lankan children with asthma. Pediatr Int, 2009; 51(2): 241-5.

90. Ljungstrom I, Van Knapen F. An epidemiological and serological study of Toxocara infection in Sweden. Scand J Infect Dis, 1989; 21(1): 87-93.
91. Sharghi N, Schantz PM, Caramico L, Ballas K, Teague BA, Hotez PJ. Environmental exposure to Toxocara as a possible risk factor for asthma: a clinic-based case-control study. Clin Infect Dis, 2001; 32(7): 111-6.

92. Turrientes MC, Perez de Ayala A, Norman F, Navarro M, Perez-Molina JA, Rodriquez-Ferrer M, et al. Visceral larva migrans in immigrants from Latin America. Emerg Infect Dis, 2011; 17(7): 1263-5.

93. Kuman HA, Altıntaș N. Ege Bölgesinde serolojik olarak saptanan toxocariasis olguları. Türkiye Parazitol Derg, 1984; 7(2): 113-9.

94. Beaver PC, Jung RC, Cupp EW. Visceral larva migrans. In: Febiger L, eds. Clinical Parasitology. 9th Ed. Philadelphia, 1984; 320-2.

95. Jacquier P, Gottstein B, Stingelin Y, Eckert J. Immunodiagnosis of toxocarosis in humans: evaluation of a new enzyme-linked immunosorbent assay kit. J Clin Microbiol, 1991; 29(9): 1831-5.

96. Yamasaki H, Araki K, Lim PK, Zasmy N, Mak JW, Taib R, Aoki T. Development of a highly specific recombinant Toxocara canis second-stage larva excretory-secretory antigen for immunodiagnosis of human toxocariasis. J Clin Microbiol, 2000; 38(4): 1409-13.

97. Schantz PM, Meyer D, Glickman LT. Clinical, serologic, and epidemiologic characteristics of ocular toxocariasis. Am J Trop Med Hyg, 1979; 28(1): 24-8.

98. Nicoletti A, Sofia V, Mantella A, Vitale G, Contrafatto D, Sorbello V, et al. Epilepsy and toxocariasis: a case-control study in Italy. Epilepsia, 2008; 49(4): 594-9.

99. Park HY, Lee SU, Huh S, Kong Y, Magnaval JF. A seroepidemiological survey for toxocariasis in apparently healthy residents in Gangwon-do, Korea. Korean J Parasitol, 2002; 40(3): 113-7.

100. Montalvo AM, Espino AM, Escalante G, Finlay CM. Study of the seroprevalence of toxocariasis in an infantile population in the City of Havana. Rev Cubana Med Trop, 1994; 46(3): 156-8.

101. Genchi C, Di Sacco B, Gatti S, Sangalli G, Scaglia M. Epidemiology of human toxocariasis in northern Italy. Parassitologia, 1990; 32(3): 313-9.

102. Sturchler D, Bruppacher R, Speiser F. Epidemiological aspects of toxocariasis in Switzerland. Schweiz Med Wochenschr, 1986; 116(33): 1088-93. 
103. Chan PW, Anuar AK, Fong MY, Debruyne JA, Ibrahim J. Toxocara seroprevalence and childhood asthma among Malaysian children. Pediatr Int, 2001; 43(4): 350-3.

104. Kuk S, Özel E, Oğuztürk H, Kırkıl G, Kaplan M. Seroprevalence of Toxocara antibodies in patients with adult asthma. South Med J, 2006; 99(7): 719-22.

105. Kaplan M, Kalkan A, Hosoglu S, Kuk S, Ozden M, Demirdag $\mathrm{K}$, et al. The frequency of Toxocara infection in mental retarded children. Mem Inst Oswaldo Cruz, 2004; 99(2): 121-5.

106. Rayes AA, Lambertucci JR. Human toxocariasis as a possible cause of eosinophilic arthritis. Rheumatology (Oxford), 2001; 40(1): 109-10.

107. Holland CV, Smith HV. Toxocara: The enigmatic parasite. Cambridge: CABI Publishing, 2006.

108. Gavignet B, Piarroux R, Aubin F, Millon L, Humbert P. Cutaneous manifestations of human toxocariasis. J Am Acad Dermatol, 2008; 59(6): 1031-42.

109. Humbert $P$, Niezborala $M$, Salembier $R$, Aubin $F$, Piarroux R, Buchet $S$, et al. Skin manifestations associated with toxocariasis: a case-control study. Dermatology, 2000; 201(3): 230-4.

110. Wolfrom E, Chene G, Lejoly-Boisseau H, Beylot C, Geniaux M, Taieb A. Chronic urticaria and Toxocara canis infection: a case control study. Ann Dermatol Venereol, 1996; 123(4): 240-6.

111. Gesierich A, Herzog S, Grunewald SM, Tappe D, Brocker EB, Schon MP. Eosinophilic folliculitis in a Caucasian patient: association with toxocariasis? J Eur Acad Dermatol Venereol, 2006; 20(10): 1317-21.

112. Demirci $M$, Yildirim $M$, Aridogan BC, Baysal V, Korkmaz M. Tissue parasites in patients with chronic urticaria. J Dermatol, 2003; 30(11): 777-81.

113. Logar J, Soba B, Kraut A, Stirn-Kranjc B. Seroprevalence of Toxocara antibodies among patients suspected of oculer toxocariasis in Slovenia. Korean J Parasitol, 2004; 42(3): 137-40.

114. Kwon SI, Lee JP, Park SP, Lee EK, Huh S, Park IW. Ocular toxocariasis in Korea. Jpn J Ophthalmol, 2011; 55(2): 143-7.
115. Zhou M, Chang Q, Gonzales JA, Chen Q, Zhang Y, Huang $X$, et al. Clinical characteristics of ocular toxocariasis in Eastern China. Graefes Arch Clin Exp Ophthalmol, 2012; 250(9): 1373-8.

116. Karadam SY, Ertug S, Ertabaklar H, Okyay P. The comparision of IgG antibodies specific to Toxocara spp. among eosinophilic and non-eosinophilic groups. New Microbiol, 2008; 31(1): 113-6.

117. Girdwood RW, Smith HV, Bruce RG, Quinn R. Human Toxocara infection in west of Scotland. Lancet, 1978; 1(8077): 1318.

118. Choi JH, Suh YJ, Jung JW, Song HJ, Suh $\mathrm{CH}$, Huh $S$, et al. Clinical significance of serum ECP and sero-prevalence of human toxocariasis in patients with eosinophilia. J Asthma Allergy Clin Immunol, 2003; 23(1): 26-32.

119. Sviben M, Cavlek TV, Missoni EM, Galinovic GM. Seroprevalence of Toxocara canis infection among asymptomatic children with eosinophilia in Crotia. J Helminthol, 2009; 83(4): 369-71.

120. Maraghi S, Rafiei A, Hajihossein R, Sadjjadi SM. Seroprevalence of toxocariasis in hypereosinophilic individuals in Ahwaz, SouthWestern Iran. J Helminthol, 2012; 86(2): 241-4.

121. Lambertucci JR, Rayes A, Serufo JC, Teiexira DM, Gerspacher-Lara R, Nascimento E, et al. Visceral larva migrans and tropical pyomyelitis: a case report. Rev Inst Med Trop Sao Paulo, 1998; 40(6): 383-5.

122. Glickman L, Schantz P, Dombroske R, Cypess R. Evaluation of serodiagnostic tests for visceral larva migrans. Am J Trop Med Hyg, 1978; 27(3): 492-8.

123. Özcel MA, Altıntaş N. İç organ larva göçü hastalığının serolojik yöntemlerle araștırılması. Türkiye Parazitol Derg,1987; 11(2): 88-95.

124. Ayçiçek $\mathrm{H}$, Tanyüksel $M$. Toxocara canis yumurtalariyla enfekte farelerde Toxocara canis larval ve erișkin antijenleri kullanılarak toxocariasis ELISA ve IFA teknikleri ile serolojik tanı. 11. Ulusal Parazitoloji Kongresi Poster Bildirisi. Eylül, 6-10, Sivas-Türkiye, 1999.

125. Gillespie SH, Bidwell D, Voller A, Robertson BD, Maizels RM. Diagnosis of human toxocariasis by antigen capture enzyme linked immunosorbent assay. J Clin Pathol, 1993; 46(6): 551-4. 
126. Sobota K, Kotuliakova M, Sobotova O, Krcmery V. Our experiences in the clinic and treatment of larval toxocarosis. Helminthologia, 1988; 25(1-2): 61-7.

127. Gillespie SH. Human toxocariasis. J App Bacteriol, 1987; 63(6): 473-9.

128. Stürchler D, Schubarth $P$, Gualzata $M$, Gottstein B, Oettli A. Thiabendazole vs. albendazole in treatment of toxocariasis: a clinical trial. Ann Trop Med Parasitol, 1989; 83(5): 473-8.

129. Korkmaz M. Helmintlere karșı kullanılan yeni ilaçlar. ANKEM Derg, 2012; 26(Ek 2): 121-6.

130. Hotez PJ. Toxocara canis. In: Burg FD, Wald ER, Ingelfinger JR, and Polin PA, eds. Gellis and Kaganis current pediatric therapy. 15th ed. Philadelphia. W.B. Saunders Pubs, 1995: 683-4.
131. Beaver PC. Zoonoses, with particular reference to parasites of veterinary importance. In: Soulsby EJL, eds. Biology of Parasites. New York. Academic Press Inc, 1966: 215-8.

132. Fernando SD, Wickramasinghe VP, Kapilananda GM, Devasurendra RL, Amarasooriya JD, Dayaratne HG. Epidemiological aspects and risk factors of toxocariasis in a pediatric population in Sri Lanka. Southeast Asian J Trop Med Public Health, 2007; 38(6): 983-90.

133. Ruiz de Ybanez MR, Garijo M, Goyena M, Alonso FD. Improved methods for recovering eggs of Toxocara canis from soil. J Helminthol, 2000; 74(4): 349-53. 